\title{
FIELD COMPARISON OF SEISMIC SOURCES FOR HIGH RESOLUTION SHALLOW SEISMIC REFLECTION PROFILING ON THE LJUBLJANA MOOR (CENTRAL SLOVENIA)
}

\author{
Jure ATANACKOV ${ }^{1), *}$ and Andrej GOSAR ${ }^{2)}$ \\ ${ }^{1)}$ Geological Survey of Slovenia, Dimičeva 14, 1000 Ljubljana, Slovenia \\ 2) University of Ljubljana, Faculty of Natural Sciences and Engineering and Slovenian Environment Agency, \\ Seismology and geology office, Dunajska 47, 1000 Ljubljana, Slovenia \\ *Corresponding author's e-mail: jure.atanackov@geo-zs.si
}

(Received August 2012, accepted January 2013)

\begin{abstract}
Two seismic sources were tested on different surfaces during acquisition of a 5.5-km long high resolution seismic reflection (HRS) profile on the Ljubljana Moor in central Slovenia. Maximum target depth range of the survey was $200-300 \mathrm{~m}$. Nine different combinations of source-surface conditions were analysed. Seismic sources included a seismic shotgun and an accelerated weight dropper system. The HRS profile crossed different surfaces including: paved roads, gravel roads, ploughed fields, grasslands and marshlands. Seismic source performance on different surfaces was evaluated through frequency and $\mathrm{S} / \mathrm{N}$ ratio analyses of seismic data, and analysis of source-generated coherent noise appearance on seismograms. Results show that both seismic sources are suitable for some of the surfaces found in the surveyed area. The accelerated weight dropper produced the best results on gravel road surface, but poor results were found on grassland and ploughed fields. The seismic shotgun produced the best results in water-saturated soil on marshlands. It performed less favourably in unsaturated soil, generating more coherent noise. Water-saturated marshland surface and gravel road surfaces were found to be the most favourable for acquisition of high-resolution seismic reflection data on the Ljubljana Moor.
\end{abstract}

KEYWORDS: high-resolution shallow seismic reflection, seismic source comparison, seismic source characteristics, seismic shotgun, accelerated weight dropper

\section{INTRODUCTION}

The seismic reflection method is based on reflection of artificially generated seismic waves from subsurface structures. Seismic waves reflect from boundaries within rocks and sediments where a significant contrast in seismic impedance exists. These may be beddings, faults, erosional discontinuities, etc. Since the 1980s and 1990s, the seismic reflection method has been progressively more used in shallow surveys too and has become known as high-resolution seismic reflection (HRS) method. Although the HRS method was derived from deep oil and gas seismic reflection method it is less routine and requires a site-specific approach, due to greater influence of near-surface conditions, the presence of a heterogeneous low-velocity layer, sensitivity to groundwater level and water saturation of near-surface sediments.

The capacity of shallow, HRS surveys has been well proven. It is highly useful in shallow surveys of unconsolidated, non-lithified, partially consolidated and lithified sediments (Wyatt et al., 1996; Büker et al., 1998; Bachrach et al., 1998; Bachrach and Nur, 1998; Steeples and Miller, 1998; Francese et al., 2007). The depth range of the method is between several meters up (ultra high-resolution seismic reflection) to several hundreds of meters with high vertical and lateral resolution (Pullan and Hunter, 1990; Steeples and Miller, 1990; Miller and Steeples, 1991; Feroci et al., 2000; Steeples, 2000). The method is highly successful in stand-alone applications (Wang et al., 2001; Dusar et al., 2001; Sugiyama et al., 2003; Campbell, 2009; Bruno et al., 2010; Green et al., 2010) and in conjunction with other methods such as Ground Penetrating Radar and geoelectrical methods (Abbott and Louie, 2001; Chow et al., 2001; Improta et al., 2010; Chwatal et al., 2005; Kato et al., 2005; Bexfield et al., 2006).

The site-specific approach for this method includes suitable data acquisition parameters and a proper seismic source and geophone choice (Knapp and Staples, 1986; Miller et al., 1994; Steeples and Miller, 1998; Steeples, 2000). Seismic source choice is the most important as various sources have different energy and frequency content, dominant frequencies, source wavelets and effectiveness under different geological and near-surface conditions. Other important factors in seismic source selection include: portability, cost of operation, site preparation requirements, source repeatability and time cycle between shots, environmental damage and safety requirements. Various seismic sources have been 
tested in different geological conditions. Miller et al. (1986) tested 15 different seismic sources, including a piezoelectric source, a sledgehammer, various seismic rifles and shotguns, various weight drop systems and various types and amounts of explosives. Similar tests by Miller et al. (1992) and Miller et al. (1994) included 13 and 12 different seismic sources, respectively. An extensive analysis of an in-hole shotgun source was described by Pullan and MacAulay (1987). General findings include a wide variability of seismic source energies, ranging over several orders of magnitude and changes in relative effectiveness of sources depending on the survey target depth, water saturation of surface material, depth of water table, compaction and a grain size of shallow subsurface material.

We tested two different seismic sources: an accelerated weight dropper system and a seismic shotgun. Our motivation was to determine the optimal seismic source - ground surface combination for various types of surfaces encountered on the Ljubljana Moor. Frequency spectra and signal-to-noise $(\mathrm{S} / \mathrm{N})$ ratios were analysed for a number of combinations of sources and surfaces as well as properties of source generated coherent noise.

\section{GEOLOGICAL SETTING}

Seismic sources were tested on the Ljubljana Moor (Figure 1), a Quaternary tectonic basin filled with up to $150 \mathrm{~m}$ of fluvial and lacustrine sediments. There are several motivations for geophysical investigations, since the area is interesting from different geological standpoints. As a part of the greater Ljubljana basin area it is an area of significant seismic hazard with prominent historical earthquake activity. Due to large thicknesses of unconsolidated Quaternary sediments pronounced seismic site effects and local seismic wave amplifications are expected in the area. Several regional (Dinaric, NW-SE trending) faults, including Želimlje and Ortnek faults, cross the eastern part of Ljubljana Moor (Figure 1). Whereas these faults have pronounced surface traces north and south of the Moor, their exact locations and relationships within the basin are poorly constrained (Premru, 1983; Mencej, 1989; Bavec et al., 2009). Studies of the most damaging $\mathrm{M}=6.11895$ Ljubljana earthquake macroseismic data suggest that the earthquake occurred along a Dinaric fault.

The Quaternary sediments of the Ljubljana Moor also contain important aquifer systems, providing fresh water to communities on the Moor and to Ljubljana, the capital of Slovenia. Aquifer structure is very complex, due to the complex basement structure, sedimentation and relationship between alluvial sediments of different rivers flowing into the basin (Breznik, 1975; Mencej, 1989). All these factors make HRS method a potentially powerful tool for the study of the structure of Quaternary sediment and preQuaternary basement morphology on the Ljubljana Moor.

\section{SITE CHARACTERISTICS}

On the surface of the Ljubljana Moor, the upper 10 to $50 \mathrm{~cm}$ thick layer is very heterogeneous, depending on the location. In marshlands and grasslands it is represented by hydromorphic grounds, other locations feature an anthropogenic layer, either a ploughed layer or a gravel layer. This layer is underlain by an up to $20 \mathrm{~m}$ thick succession of Holocene lacustrine sediments, composed of clay layers with different thicknesses, ranging from $<10 \mathrm{~cm}$ to $15 \mathrm{~m}$. The lacustrine clay is underlain by a succession of alternating middle and late Pleistocene lacustrine clays and alluvial sands and gravels down to the pre-Quaternary basement (Šercelj, 1965; Grmiščar and Ocepek, 1967). It is expected that the alternating clays, sands and gravels produce distinct seismic horizons, but their lateral continuity is questionable due to the heterogeneous sedimentation.

A very strong seismic horizon is expected at the pre-Quaternary basement, composed of Triassic limestone and dolomite or Permian and Carboniferous sandstones and conglomerates. The depth to the basement is variable. Previous geophysical investigations (vertical electrical sounding and seismic refraction) and borehole data have shown the depth of the pre-Quaternary basement in the investigated area to range between 100 and $180 \mathrm{~m}$.

The groundwater level in the area is always high. Depending on the amount of precipitation the water table was at the depth between $\sim 1.5 \mathrm{~m}$ and $0.1 \mathrm{~m}$ during the course of data acquisition.

The large majority of the site is characterised by low ambient noise, mostly generated by wind gusts and vegetation. Rarely there was some mechanical noise from nearby fields, but data acquisition was paused during periods of increased noise. In several localised areas, close to major roads and railway lines, noise from traffic is present and data acquisition was undertaken during low traffic density periods (close to noon or at night). In the small settled area (Kožuh), just west of the Ljubljana-Ig road, buildings acted as reflecting interfaces for source-generated, air-coupled waves.

\section{FIELD PROCEDURES EQUIPMENT}

Data was acquired using two 24-channel ABEM Terraloc VI 18-bit seismographs in master-slave mode. Both were connected to a custom made 96channel input / 48-channel output rollalong switch. Seismic lines consisted of 100 geophones $(40 \mathrm{~Hz})$, connected to 12-channel seismic cables. Two different seismic sources were used: a GISCO ESS100 accelerated weight dropper and a custom made seismic shotgun.

The GISCO ESS100 is a car-mounted electric seismic source (Figure 2). It is an accelerated weight dropper system using an elastomer band to spring load the $45.5 \mathrm{~kg}(100 \mathrm{lb})$ weight. The source was first used 


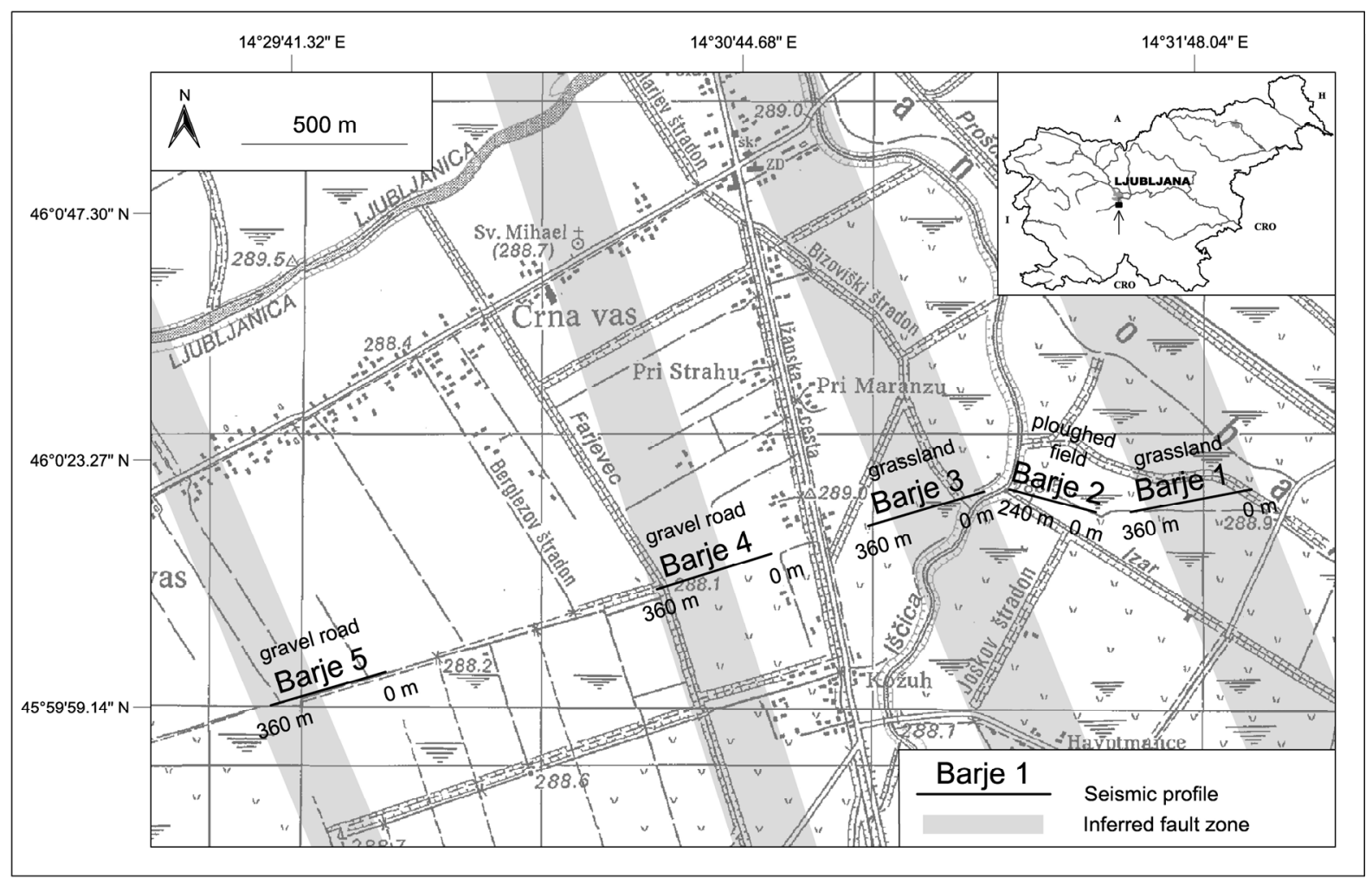

Fig. 1 Location of seismic source testing sites and seismic profiles on the Ljubljana Moor with marked surface types and inferred fault zone positions from (Premru, 1983; Mencej, 1989; Bavec et al., 2009).

with a $1 \mathrm{kN} / \mathrm{m}$ elastomer band, which was later replaced with a $\sim 4 \mathrm{kN} / \mathrm{m}$ rubber band. The source is mounted $40 \mathrm{~cm}$ above the ground. A $20 \times 20 \times 2 \mathrm{~cm}$ iron plate acts as interface between the weight and the ground. The elastic band maximum dilatation is about $1.6 \mathrm{~m}$, giving an approximate source energy of $1.5 \mathrm{~kJ}$ with the $1 \mathrm{kN} / \mathrm{m}$ elastomer band and about $5 \mathrm{~kJ}$ with the $4 \mathrm{kN} / \mathrm{m}$ rubber band.

The custom made seismic shotgun consists of a $120 \mathrm{~cm}$ long metal body with a manual springloaded firing mechanism (Figure 2). The barrel consists of a reinforced firing chamber on the firing end of the shotgun, made to fit 12-gauge Cheddite Trap shells. The shells were custom made, using a 3$\mathrm{cm}$ long aluminium cylinder instead of birdshot and double the explosive charge $(60 \mathrm{~g})$ of ordinary 12gauge shells. The shotgun is fitted with a $60 \times 40 \mathrm{~cm}$ carbon fibre board acting as stabiliser and air wave suppressor. The firing depth is adjustable between 20 and $80 \mathrm{~cm}$.

\section{DATA ACQUISITION}

Data was acquired with a spread of one hundred $40 \mathrm{~Hz}$ geophones spaced $2 \mathrm{~m}$ apart and 48 active channels. The geometry was on-end with a near offset of $2 \mathrm{~m}$. Shot gathers made with the ESS100 weight dropper contain four stacked shots and the shot gathers made with the seismic shot gun contain a single shot. Shot depth was kept constant at $50 \mathrm{~cm}$ in pre-made shot holes. No additional water was applied.
Seismic data was acquired with $100 \mu$ s sampling and 16384 samples without analogue pre-filter.

All data was obtained on the Ljubljana Moor in the course of the acquisition of a $5.5-\mathrm{km}$ long HRS line. The seismic line crossed varied terrain, including: well consolidated gravel roads, paved (asphalt) roads, grassland, marshes and ploughed fields. Different seismic sources were used depending on accessibility. The accelerated weight dropper was used in areas with good 4WD car access: gravel roads, grassland and ploughed fields. The seismic shotgun was used in areas with limited access, mostly marshlands. Ground surface types and seismic sources for each profile shown in Figure 1 are listed in Table 1.

Different surface types have different elastic properties, porosity and water saturation. These are directly reflected in seismic source energy absorption and seismic wave attenuation. Surface types found on this seismic line include:

Marshland - includes several different types of land surface, all with high water saturation: grassland with very shallow groundwater table $(<0.5 \mathrm{~m})$, roadside ditches (along gravel roads) and irrigation channels (used when water level was low).

Grassland - is generally elastic, but in the investigated area ranged from very soft and elastic (in some areas each step produces a temporary depression) to compact and hard. The shallow subsurface was damp, but never water-saturated (groundwater table below $\sim 0.5 \mathrm{~m}$ ). 
Table 1 List of seismic profiles (shown in Figure 1), corresponding ground surfaces and used seismic sources.

\begin{tabular}{lll}
\hline Profile & Ground surface & Seismic source \\
\hline Barje 1 & $\begin{array}{l}\text { grassland (eastern half unsaturated, damp, compact } \\
\text { soil, western half drier and more porous soil) }\end{array}$ & $\begin{array}{l}\text { 12-gauge seismic shotgun } \\
\text { (ESS100 accelerated weight dropper } \\
\text { also tested) }\end{array}$ \\
\hline Barje 2 & ploughed field & ESS100 accelerated weight dropper \\
\hline Barje 3 & $\begin{array}{l}\text { grassland (highly variable water saturation and } \\
\text { level of compaction, from highly water-saturated to } \\
\text { dry, soft and elastic to hard and compact) }\end{array}$ & ESS100 accelerated weight dropper \\
\hline Barje 4 & gravel road & ESS100 accelerated weight dropper \\
\hline Barje 5 & gravel road & ESS100 accelerated weight dropper \\
\hline
\end{tabular}
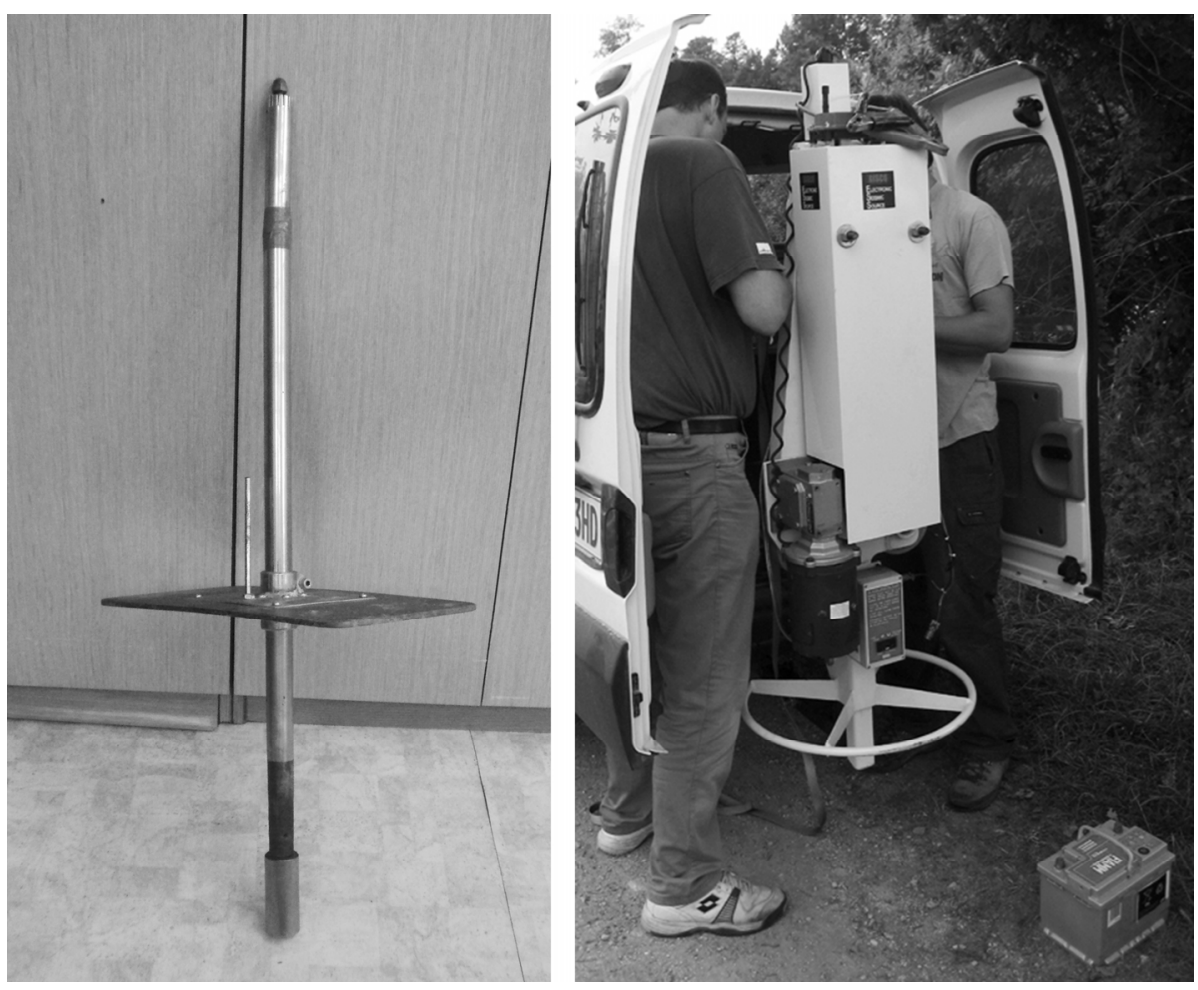

Fig. 2 Seismic sources used in field testing. Left: custom made 12-gauge seismic shotgun (image courtesy of Robert Stopar, Geoinženiring d.o.o.) Right: GISCO ESS100 accelerated weight dropper.

Gravel roads - were made of crushed limestone and dolomite gravel in thicknesses $50-200 \mathrm{~cm}$ and well consolidated. Only the accelerated weight dropper was used, as the seismic shotgun would require destructive shot holes preparation. Geophones were planted on the road edge deep into the gravel.

Ploughed fields - a single ploughed field was crossed. The surface was a very soft and porous gyttja up to a depth of about $0.5 \mathrm{~m}$ with the characteristic "polžarica" clay below.

Asphalt road - a short part of a gravel road was asphalted and allowed testing of this surface type as well. Geophones were planted on the road edge into gravel.

\section{DATA ANALYSIS}

Seismic data was processed and analysed with Parallel Geoscience Seismic Processing Workshop (SPW) software. All shot gathers were processed in the following way: first the average frequency spectrum of 40 shot gathers for the entire $(2-96) \mathrm{m}$ offset interval and $0-400 \mathrm{~ms}$ two-way traveltime (TWT) interval was determined for each seismic source - surface type combination. Then, analysis windows were defined by offset and TWT intervals for reflections and coherent noise types (Table 2). For each seismic source - surface type combination, 20 shot gathers were analysed and the average and median dominant frequencies were 
Table 2 Analysis windows for significant signals (reflections and coherent noise).

\begin{tabular}{lcc}
\hline Signal & $\begin{array}{c}\text { Offset interval } \\
(\mathbf{m})\end{array}$ & $\begin{array}{c}\text { TWT interval } \\
(\mathbf{m s})\end{array}$ \\
\hline Reflections & $24-96$ & $50-150$ \\
\hline Refractions & $24-40$ & $30-50$ \\
\hline Ground roll & $2-24$ & $150-400$ \\
\hline Air-coupled & where most & where most \\
wave & pronounced & pronounced \\
\hline Guided & where most & where most \\
waves & pronounced & pronounced \\
\hline
\end{tabular}

Table $3 \mathrm{~S} / \mathrm{N}$ ratios for different combinations of seismic sources and surfaces.

\begin{tabular}{|c|c|}
\hline Seismic source and surface & $\mathrm{S} / \mathrm{N}$ ratio \\
\hline Shotgun + saturated soil (marshland) & $5.8 \pm 2.0$ \\
\hline $\begin{array}{l}\text { Shotgun }+ \text { unsaturated soil } \\
\text { (grassland) }\end{array}$ & $4.1 \pm 2.3$ \\
\hline $\begin{array}{l}\text { ESS100 accelerated weight } \\
\text { dropper }+1 \mathrm{kN} / \mathrm{m} \text { elastomer band } \\
+ \text { aluminium plate on hardened } \\
\text { gravel road surface }\end{array}$ & $9.4 \pm 4.4$ \\
\hline $\begin{array}{l}\text { ESS100 accelerated weight dropper } \\
+4 \mathrm{kN} / \mathrm{m} \text { rubber band }+ \text { iron plate } \\
\text { on hardened paved (asphalt) road } \\
\text { surface }\end{array}$ & $12.3 \pm 11.1$ \\
\hline $\begin{array}{l}\text { ESS100 accelerated weight dropper } \\
+4 \mathrm{kN} / \mathrm{m} \text { rubber band }+ \text { iron plate } \\
\text { on hardened gravel road surface }\end{array}$ & $3.7 \pm 1.3$ \\
\hline $\begin{array}{l}\text { ESS100 accelerated weight dropper } \\
+4 \mathrm{kN} / \mathrm{m} \text { rubber band }+ \text { iron plate } \\
\text { on grassland surface }\end{array}$ & $6.1 \pm 3.0$ \\
\hline $\begin{array}{l}\text { ESS100 accelerated weight dropper } \\
+4 \mathrm{kN} / \mathrm{m} \text { rubber band + iron plate } \\
\text { on ploughed field surface }\end{array}$ & $2.8 \pm 1.5$ \\
\hline
\end{tabular}

determined together with standard deviation for reflections and each coherent noise type (significant signals). Analysis results are summarised in Tables 4, 5 and 6.

To analyse the attenuation of seismic waves on different surface types, $\mathrm{S} / \mathrm{N}$ ratio of 4 traces with largest offset (channels $45-48$, offsets $90-96 \mathrm{~m}$ ) was determined in the $50-250 \mathrm{~ms}$ TWT interval, where useful reflection signals were expected (Table 3).

All shot gathers displayed in this paper (Figures 3 - 12) show the following processing steps: raw shot gather on the upper left, the same shot gather with AGC ( $80 \mathrm{~ms}$ window) and spectral whitening (10 - $150 \mathrm{~Hz}$ ) on the upper right and a frequency spectrum in the lower part of the figure with annotated dominant frequency of the shot gather (note that this is not the dominant frequency of reflections).

\section{GENERAL SIGNAL-TO-NOISE RATIO ANALYSIS}

Signal-to-noise $(\mathrm{S} / \mathrm{N})$ ratio analysis was performed for 7 different seismic source - surface type combinations (Table 3 ). All $\mathrm{S} / \mathrm{N}$ ratios are in the same order of magnitude, implying similar energies for both seismic sources. The seismic shotgun produces a fairly similar $\mathrm{S} / \mathrm{N}$ ratio for shots into saturated and unsaturated soil, although a significant improvement was observed in shots into saturated soil. The ESS100 accelerated weight dropper S/N ratio results show more variability, over an entire order of magnitude, from the lowest value of $2.8 \pm 1.5$, obtained on grassland surface to the highest value of $12.3 \pm 11.1$, obtained on paved road surface.

While $\mathrm{S} / \mathrm{N}$ ratios are illustrative of seismic source energy and efficiency of source energy ground coupling and are a measure of data quality, other factors such as the presence of coherent source-

Table 4 Significant signal dominant frequencies for seismic data obtained with the seismic shotgun used in saturated and unsaturated soil.

Seismic shotgun + unsaturated soil (grassland)

\begin{tabular}{|c|c|c|c|c|c|}
\hline & Reflections (Hz) & Refractions (Hz) & $\begin{array}{c}\text { Air-coupled } \\
\text { wave }(\mathrm{Hz})\end{array}$ & $\begin{array}{l}\text { Ground } \\
\text { roll }(\mathrm{Hz})\end{array}$ & $\begin{array}{c}\text { Guided waves } \\
(\mathrm{Hz})\end{array}$ \\
\hline Average & 36.7 & 87.8 & 36.9 & 35.4 & None \\
\hline Median & 35.0 & 87.6 & 39.0 & 35.9 & None \\
\hline Standard deviation & 12.7 & 37.1 & 4.9 & 4.5 & None \\
\hline
\end{tabular}

Seismic shotgun + saturated soil (marshland)

\begin{tabular}{lccccc}
\hline & & & Air-coupled & Ground & Guided waves \\
& Reflections $(\mathrm{Hz})$ & Refractions $(\mathrm{Hz})$ & wave $(\mathrm{Hz})$ & roll $(\mathrm{Hz})$ & None \\
\hline Average & 41.2 & 57.7 & 43.5 & None & None \\
Median & 41.5 & 56.1 & 44.0 & None & None \\
Standard deviation & 7.6 & 25.4 & 5.6 & None & none \\
\hline
\end{tabular}


Table 5 Significant signal dominant frequencies for seismic data obtained with the ESS100 accelerated weight dropper with $1 \mathrm{kN} / \mathrm{m}$ elastomer and $4 \mathrm{kN} / \mathrm{m}$ rubber band. Double peaks appear for reflection and refraction signals with the $4 \mathrm{kN} / \mathrm{m}$ rubber band. The expression 29.7/80.14 (@-0,02 dB at 67\%) means a secondary peak which appears at $80.14 \mathrm{~Hz}$ with $-0.02 \mathrm{~dB}$ strength compared to the primary peak and is present in $67 \%$ of shot gathers.

\begin{tabular}{|c|c|c|c|c|c|}
\hline & Reflections (Hz) & Refractions (Hz) & $\begin{array}{c}\text { Air- } \\
\text { coupled } \\
\text { wave }(\mathrm{Hz})\end{array}$ & $\begin{array}{l}\text { Ground } \\
\text { roll }(\mathrm{Hz})\end{array}$ & $\begin{array}{c}\text { Guided } \\
\text { waves } \\
(\mathrm{Hz})\end{array}$ \\
\hline Average & $\begin{array}{l}29.6 / 80.1(@- \\
0.02 \text { dB at } 67 \%)\end{array}$ & $88.3 / 151.2(0.0 \mathrm{~dB}$ at $50 \%)$ & None & 32.2 & None \\
\hline Median & $29.1 / 78$ & $78.0 / 155.5$ & None & 31.7 & None \\
\hline Standard deviation & $3.7 / 4.8$ & $8.8 / 10.0$ & None & 4.9 & None \\
\hline \multicolumn{6}{|c|}{ ESS100: $1 \mathrm{kN} / \mathrm{m}$ elastomer band + gravel road surface + aluminium plate } \\
\hline & Reflections (Hz) & Refractions $(\mathrm{Hz})$ & $\begin{array}{c}\text { Air- } \\
\text { coupled } \\
\text { wave }(\mathrm{Hz})\end{array}$ & $\begin{array}{l}\text { Ground } \\
\text { roll }(\mathrm{Hz})\end{array}$ & $\begin{array}{c}\text { Guided } \\
\text { waves } \\
(\mathrm{Hz})\end{array}$ \\
\hline Average & 40.4 & 81.6 & None & 24.5 & None \\
\hline Median & 36.7 & 78.8 & None & 24.2 & None \\
\hline Standard deviation & 11.1 & 25.3 & None & 4.2 & None \\
\hline
\end{tabular}

Table 6 Significant signal dominant frequencies for seismic data obtained with the GISCO ESS100 accelerated weight dropper with $4 \mathrm{kN} / \mathrm{m}$ rubber band on various surfaces - grassland, gravel road and ploughed field (and a short, $60 \mathrm{~m}$ long section of asphalt road).

\begin{tabular}{lccccc}
\hline \multicolumn{2}{l}{ ESS100: $\mathbf{4} \mathbf{~ k N / m}$ rubber band + hardened gravel road surface + iron plate } & & & \\
\hline & $\begin{array}{c}\text { Reflections } \\
(\mathrm{Hz})\end{array}$ & Refractions $(\mathrm{Hz})$ & $\begin{array}{c}\text { Air-coupled } \\
\text { wave }(\mathrm{Hz})\end{array}$ & $\begin{array}{c}\text { Ground roll } \\
(\mathrm{Hz})\end{array}$ & $\begin{array}{c}\text { Guided waves } \\
(\mathrm{Hz})\end{array}$ \\
\hline Average & $29.6 / 80.2$ & $88.3 / 151.2(@ 0.0 \mathrm{~dB}$ at $50 \%)$ & None & 32.2 & None \\
Median & $29.1 / 78$ & $78.0 / 155.5$ & None & 31.7 & None \\
Standard deviation & $3.7 / 4.8$ & $8.8 / 10.0$ & None & 4.9 & None \\
\hline
\end{tabular}

ESS100: $4 \mathrm{kN} / \mathrm{m}$ rubber band + paved (asphalt) road surface + iron plate

\begin{tabular}{|c|c|c|c|c|c|}
\hline & $\begin{array}{c}\text { Reflections } \\
(\mathrm{Hz})\end{array}$ & Refractions (Hz) & $\begin{array}{c}\text { Air-coupled } \\
\text { wave }(\mathrm{Hz})\end{array}$ & $\begin{array}{c}\text { Ground roll } \\
(\mathrm{Hz})\end{array}$ & $\begin{array}{c}\text { Guided waves } \\
(\mathrm{Hz})\end{array}$ \\
\hline Average & 60.0 & 71.2 & None & 36.0 & None \\
\hline Median & 67.8 & 68.8 & None & 34.3 & None \\
\hline Standard deviation & 11.6 & 13.0 & None & 3.0 & None \\
\hline
\end{tabular}

ESS100: $4 \mathrm{kN} / \mathrm{m}$ rubber band + grassland surface + iron plate

\begin{tabular}{lccccc}
\hline & $\begin{array}{c}\text { Reflections } \\
(\mathrm{Hz})\end{array}$ & Refractions $(\mathrm{Hz})$ & $\begin{array}{c}\text { Air-coupled } \\
\text { wave }(\mathrm{Hz})\end{array}$ & $\begin{array}{c}\text { Ground roll } \\
(\mathrm{Hz})\end{array}$ & $\begin{array}{c}\text { Guided waves } \\
(\mathrm{Hz})\end{array}$ \\
\hline Average & 32.2 & 43.1 & 60.5 & 14.8 & None \\
Median & 33.0 & 39.2 & 39.5 & 14.8 & None \\
Standard deviation & 4.8 & 15.7 & 42.9 & 3.3 & None \\
\hline
\end{tabular}

ESS100: $4 \mathrm{kN} / \mathrm{m}$ rubber band + ploughed field surface + iron plate

\begin{tabular}{lccccc}
\hline & $\begin{array}{c}\text { Reflections } \\
(\mathrm{Hz})\end{array}$ & Refractions $(\mathrm{Hz})$ & $\begin{array}{c}\text { Air-coupled } \\
\text { wave }(\mathrm{Hz})\end{array}$ & $\begin{array}{c}\text { Ground roll } \\
(\mathrm{Hz})\end{array}$ & $\begin{array}{c}\text { Guided waves } \\
(\mathrm{Hz})\end{array}$ \\
\hline Average & 28.9 & 39.4 & 222.5 & 11.6 & None \\
Median & 29.1 & 39.3 & 224.5 & 10.2 & None \\
Standard deviation & 1.6 & 0.3 & 51.5 & 3.3 & None \\
\hline
\end{tabular}




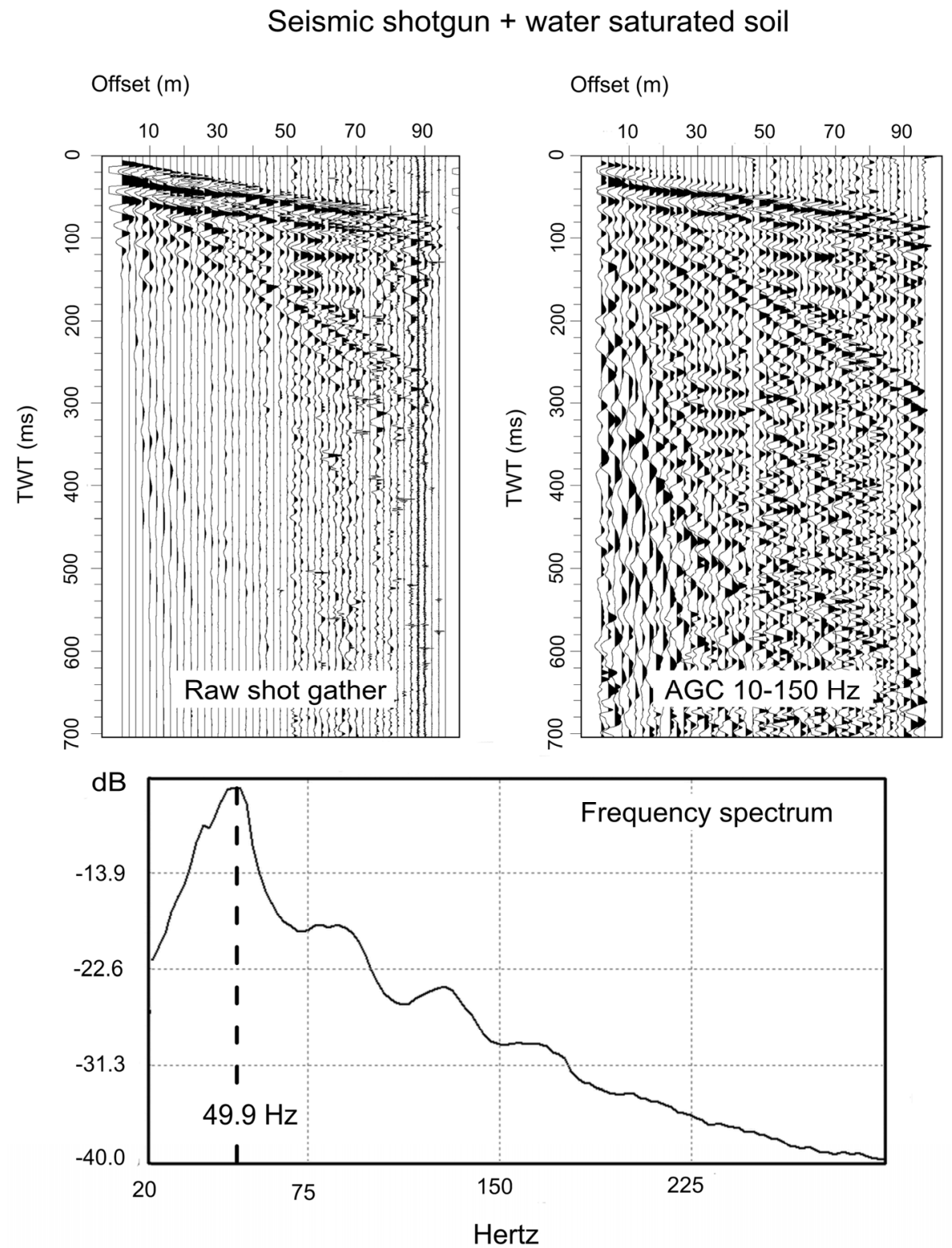

Fig. 3 Shot gather and frequency spectrum obtained with the seismic shotgun east of profile Barje 1 on the master seismic line with shots into water saturated soil. Note the near-absence of ground roll and air-coupled wave.

generated noise, strong ground roll and guided waves as well as the frequency content and dominant frequencies also influence data quality.

\section{ANALYSIS AND COMPARISON OF SHOT GATHERS}

\section{Seismic shotgun: shot into saturated vs. unsaturated soil}

Shot gathers used in this comparison were obtained on profile Barje 1 (Figure 13) and in a long, straight roadside ditch due east of profile Barje 1. The surface on Barje 1 profile is characterised as grassland with variable soil water saturation level and compaction (Table 1), while the surface along the roadside ditch is characterised as marshland with water-saturated material. Groundwater level was between $10 \mathrm{~cm}$ below and $10 \mathrm{~cm}$ above ground surface, shot depth was constant at $50 \mathrm{~cm}$. The results of this comparison are summarised in Table 4 and Figures 3 and 4.

A pronounced difference was observed in seismic shotgun shot gathers depending on whether the shot was made in saturated or unsaturated soil (Table 4, Figure 3 and Figure 4). Higher dominant frequencies were found for seismic reflections in saturated soil shot gathers $(36.7 \mathrm{~Hz}$ in unsaturated vs. $41.2 \mathrm{~Hz}$ in saturated, a $12 \%$ difference), yielding an increase in resolution of seismic data (Figure 3). However, by far the largest and most important difference is the near-complete absence of ground roll in shot gathers made with shots in saturated soil evident in Figure 3. 


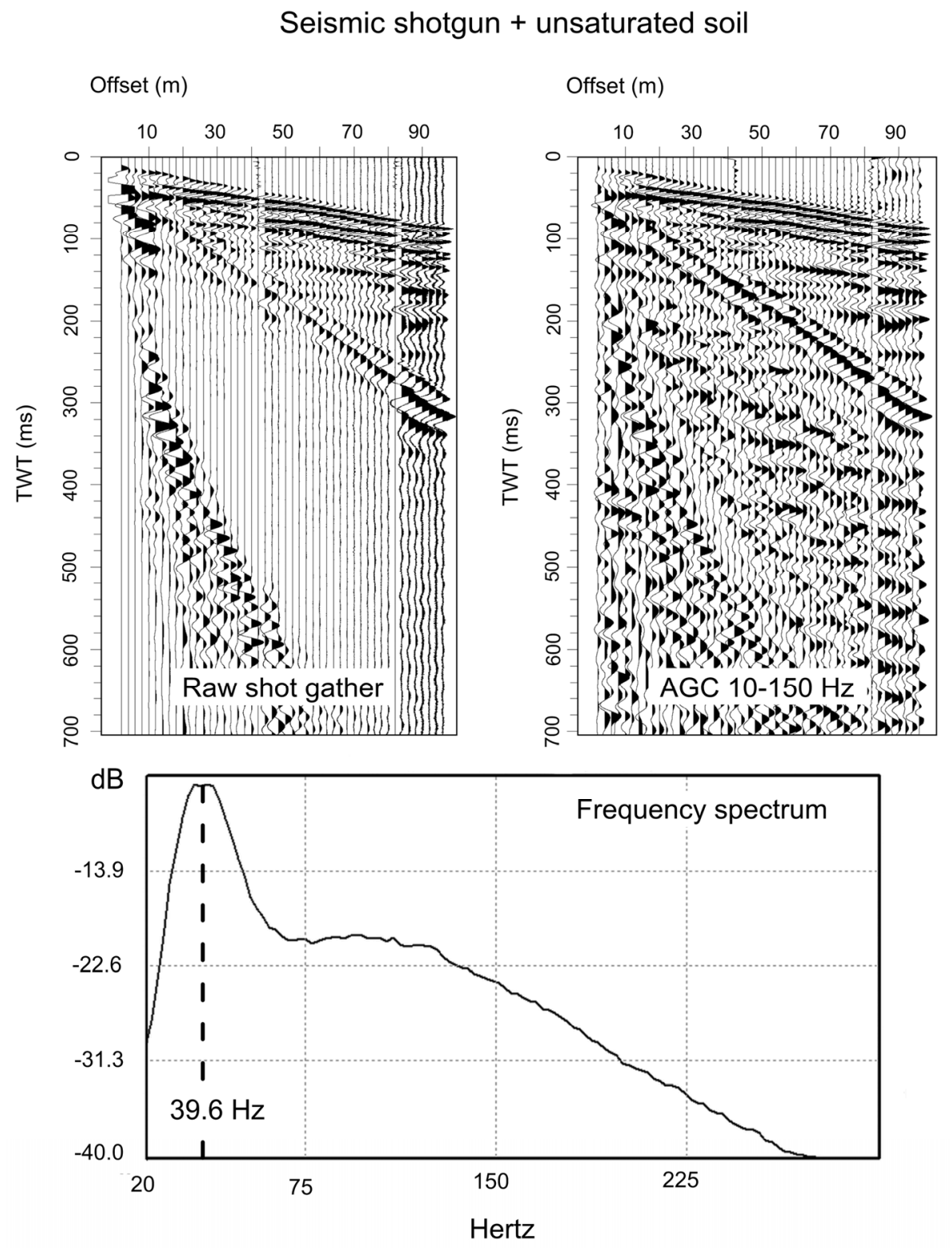

Fig. 4 Example shot gather and frequency spectrum obtained with the seismic shotgun on profile Barje 1 with shots into unsaturated soil. The dominant frequency of the shot gather is close to individual dominant frequencies of reflections and air-coupled wave (Table 4), corresponding to the strong reflections and air-coupled wave visible in the shot gather.

\section{Accelerated weight dropper vs. seismic shotgun on grassland surface}

A direct comparison was made between the ESS100 accelerated weight dropper with $4 \mathrm{kN} / \mathrm{m}$ rubber band and seismic shotgun on a particularly soft grassland surface with damp (but unsaturated), highly porous subsurface material on profile Barje 1 western end (Figure 13). Shot gathers obtained with the seismic shotgun (Figure 5) show significantly clearer seismic horizons than shot gathers obtained with the accelerated weight dropper (Figure 6). Also, the depth range is better with the seismic shotgun: shot gathers obtained with the accelerated weight dropper show clear seismic horizons only down to the distinct preQuaternary basement at approximately $150 \mathrm{~ms}$ TWT, while shot gathers obtained with the seismic shotgun show clear seismic horizons down to at least $240 \mathrm{~ms}$ TWT (Figure 5). Frequency spectra (Figures 5 and 6) show that both sources have similar dominant frequencies, but the seismic shotgun has better highfrequency content. The peak around $80 \mathrm{~Hz}$ in the ESS100 frequency spectrum is attributed to the aircoupled wave. Only five test shots were made with the accelerated weight dropper, so no statistical analysis was made due to the small data sample. To directly compare the $\mathrm{S} / \mathrm{N}$ ratio, five shot gathers obtained with 


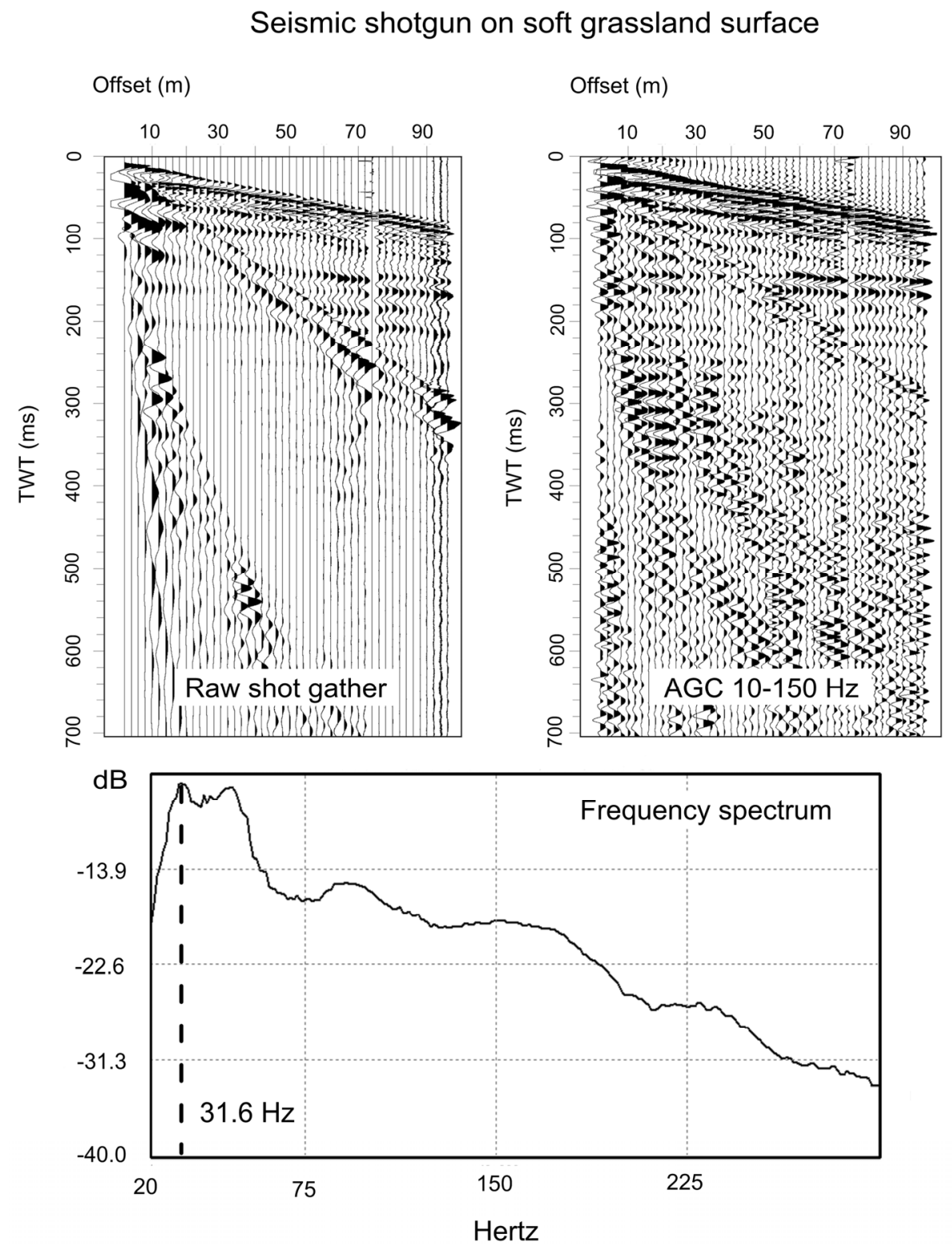

Fig. 5 Example shot gather and frequency spectrum obtained with the seismic shotgun on profile Barje 1 on a stretch of particularly soft grassland. Data quality is high: ground roll is comparatively weak, seismic reflections are well visible down to at least $250 \mathrm{~ms}$ TWT. Air-coupled wave signal is strong. The secondary peak around $45 \mathrm{~Hz}$ in the frequency spectrum is attributed to seismic reflections.

the seismic shotgun closest to the shot gathers obtained with the ESS100 were analysed.

\section{Accelerated weight dropper: different elastic bands and plates}

The GISCO ESS100 accelerated weight dropper was used on gravel roads in two configurations: with the original $1 \mathrm{kN} / \mathrm{m}$ elastomer band and aluminium plate on profile Barje 5 (Figure 17) and with the $4 \mathrm{kN} / \mathrm{m}$ rubber band and iron plate on profile Barje 4 (Figure 16). Both configurations produced very good data.
The source configuration with $4 \mathrm{kN} / \mathrm{m}$ rubber band and iron plate produced a double-peaked frequency spectrum for seismic reflections with the dominant peak at $29.6 \mathrm{~Hz}$ and a slightly weaker secondary peak at $80.1 \mathrm{~Hz}$ (Table 5). The very small standard deviation indicates high data consistency. The configuration with $1 \mathrm{kN} / \mathrm{m}$ elastomer band and aluminium plate produced a single peak at $40.4 \mathrm{~Hz}$ and a somewhat higher standard deviation. Frequency spectra show that both configurations produce considerable high-frequency content. This is evident both in shot gathers (Figures 7 and 8), where clear 

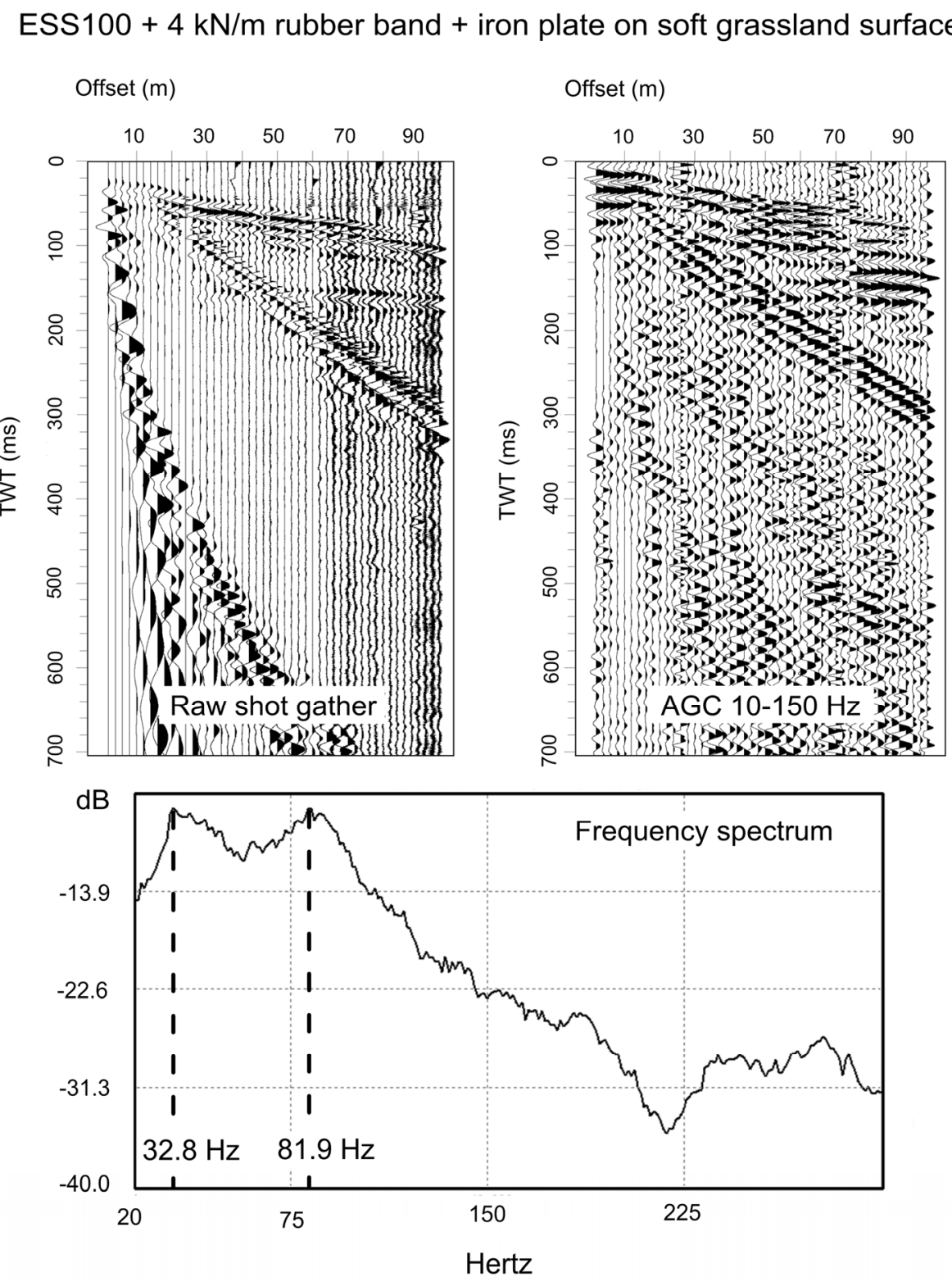

Fig. 6 Example shot gather and frequency spectrum with the ESS100 accelerated weight dropper with the $4 \mathrm{kN} / \mathrm{m}$ rubber band and iron plate obtained on a stretch of particularly soft grassland on profile Barje 1 . Note the very strong air-coupled wave and near-absence of reflections below $150 \mathrm{~ms}$ TWT.

seismic reflections are observed down to at least $300 \mathrm{~ms}$ TWT, well into the pre-Quaternary basement, and in final seismic profiles, as the two profiles obtained with these two source configurations are the finest (Figures 16 and 17). Ground roll as well as the air-coupled wave is very limited with both configurations.

\section{Accelerated weight dropper: different surfaces}

The GISCO ESS100 accelerated weight dropper with the $4 \mathrm{kN} / \mathrm{m}$ rubber band and iron plate was used on several different surfaces: gravel road on profile Barje 4 (Figure 16), paved road just east of profile
Barje 4, grassland surfaře on profile Barje 3 (Figure 15) and a ploughed field on profile Barje 2 (Figure 14). The results of comparison are summarised in Table 6 . The highest dominant frequency of reflections is observed in data from the paved road surface, followed by the data obtained on grassland, ploughed field and gravel road surface. With the exception of paved road surface, all surfaces show very similar dominant frequency around $30 \mathrm{~Hz}$ with only very small variation.

Shot gathers obtained on ploughed field surface show a high proportion of low frequency, high amplitude signals and only small content of high 


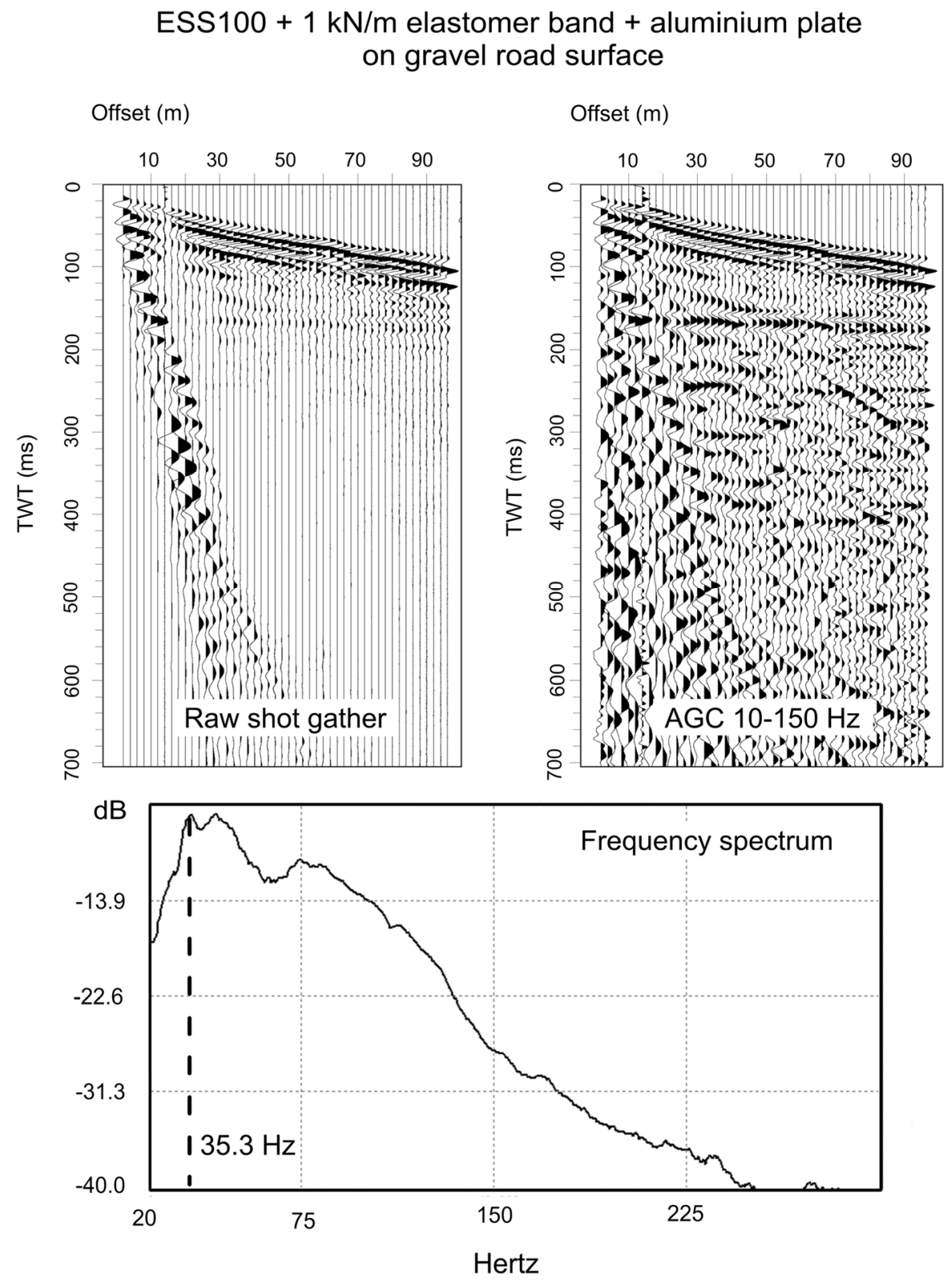

Fig. 7 Example shot gather and frequency spectrum obtained with the ESS100 accelerated weight dropper with the $1 \mathrm{kN} / \mathrm{m}$ elastomer band and aluminium plate on profile Barje 5 . The secondary peak around $40 \mathrm{~Hz}$ is produced by reflections, and the shoulder around $75 \mathrm{~Hz}$ by refractions (Table 5).

frequencies (Figure 9). This is evident also in the frequency spectrum as a near-complete absence of frequencies above $100 \mathrm{~Hz}$ (Figure 9). Shot gathers obtained on grassland surface (Figures 10, 11a and 11b) show higher variability than any other, except for shot gathers obtained on paved road surface (Figure 12 ), which is reflected in high standard deviation of reflection dominant frequency (Table 6). In general, seismic data obtained on grassland lacks high frequency content (Figure 10).

The best data in terms of high frequency content, seismic horizon clarity and data consistency with this seismic source was obtained on gravel road surface.
A double peak appears in the seismic reflection frequency spectrum with one peak at $29.6 \mathrm{~Hz}$ and another at $80.2 \mathrm{~Hz}$. A similar double peak is also seen in refraction data (Table 6). Seismic reflections are seen also in shot gathers (Figure 8) down to at least $300 \mathrm{~ms}$ TWT.

\section{EXAMPLES OF PROCESSED REFLECTION PROFILES:}

Sample profiles obtained on different surface types with different seismic sources are shown in Figures 13 - 17. On profile Barje 1 (Figure 13), acquired with the 12-gauge seismic shotgun, 


\section{ESS100 $+4 \mathrm{kN} / \mathrm{m}$ rubber band + iron plate on gravel road surface}

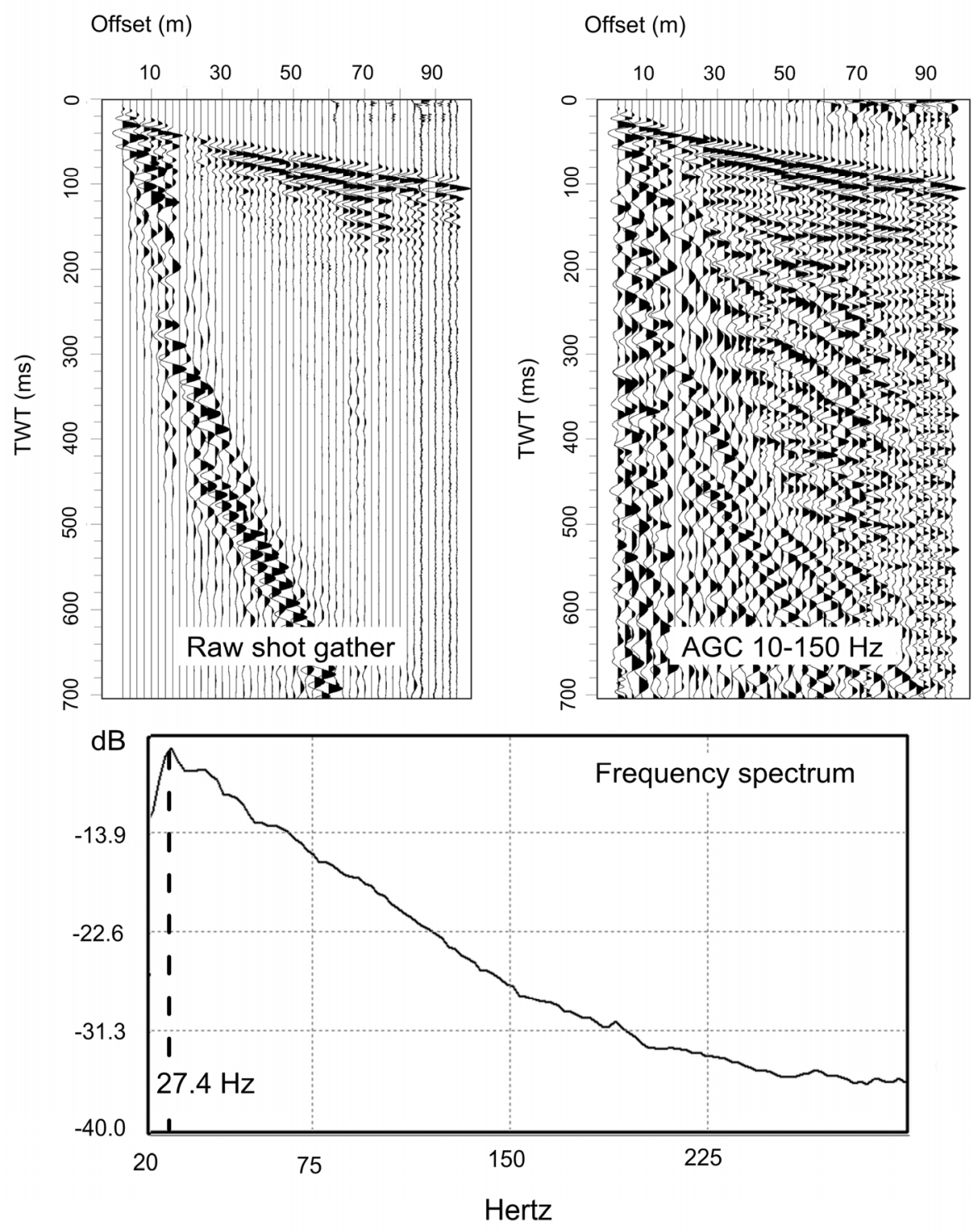

Fig. 8 Example shot gather and corresponding frequency spectrum obtained with the ESS100 accelerated weight dropper with the $4 \mathrm{kN} / \mathrm{m}$ rubber band and iron plate on gravel road surface on profile Barje 4.

discontinuous seismic reflections are visible in the eastern half of the profile (left) and more continuous reflections in the western half. The pre-Quaternary basement shows up as a distinct seismic horizon at $120 \mathrm{~ms}$ TWT at the eastern end of the profile, dipping to $130 \mathrm{~ms}$ TWT in at the western end. Profile Barje 2 (Figure 14) was acquired using the accelerated weight dropper with the $4 \mathrm{kN} / \mathrm{m}$ rubber band on a ploughed field. The pre-Quaternary basement boundary is visible as the distinct and strong seismic reflector at 155 - 165 ms TWT. Profile Barje 3 (Figure 15) was acquired on a stretch of very heterogeneous grassland surface, ranging from soft and water-saturated to hard and dry, using the accelerated weight dropper with the $4 \mathrm{kN} / \mathrm{m}$ rubber band. Big problems with data variability in terms of high frequency attenuation and source energy absorption were encountered, which are reflected in poor profile quality. The pre-Quaternary basement boundary is found at $165 \mathrm{~ms}$ TWT at the beginning of the profile and is lost around CMP 1120. Profile Barje 4 (Figure 16) was acquired using the accelerated weight dropper with the $4 \mathrm{kN} / \mathrm{m}$ rubber band on a gravel road. Data quality is very high with excellent visibility of seismic reflectors in the Quaternary sediments as well as for the preQuaternary basement at $140 \mathrm{~ms}$ TWT. Profile Barje 5 (Figure 17) was acquired using the accelerated weight dropper with the $1 \mathrm{kN} / \mathrm{m}$ rubber band on a gravel road surface. Again the data quality is very high with seismic reflectors well visible in the Quaternary 
ESS100 $+4 \mathrm{kN} / \mathrm{m}$ rubber band + iron plate on ploughed field surface
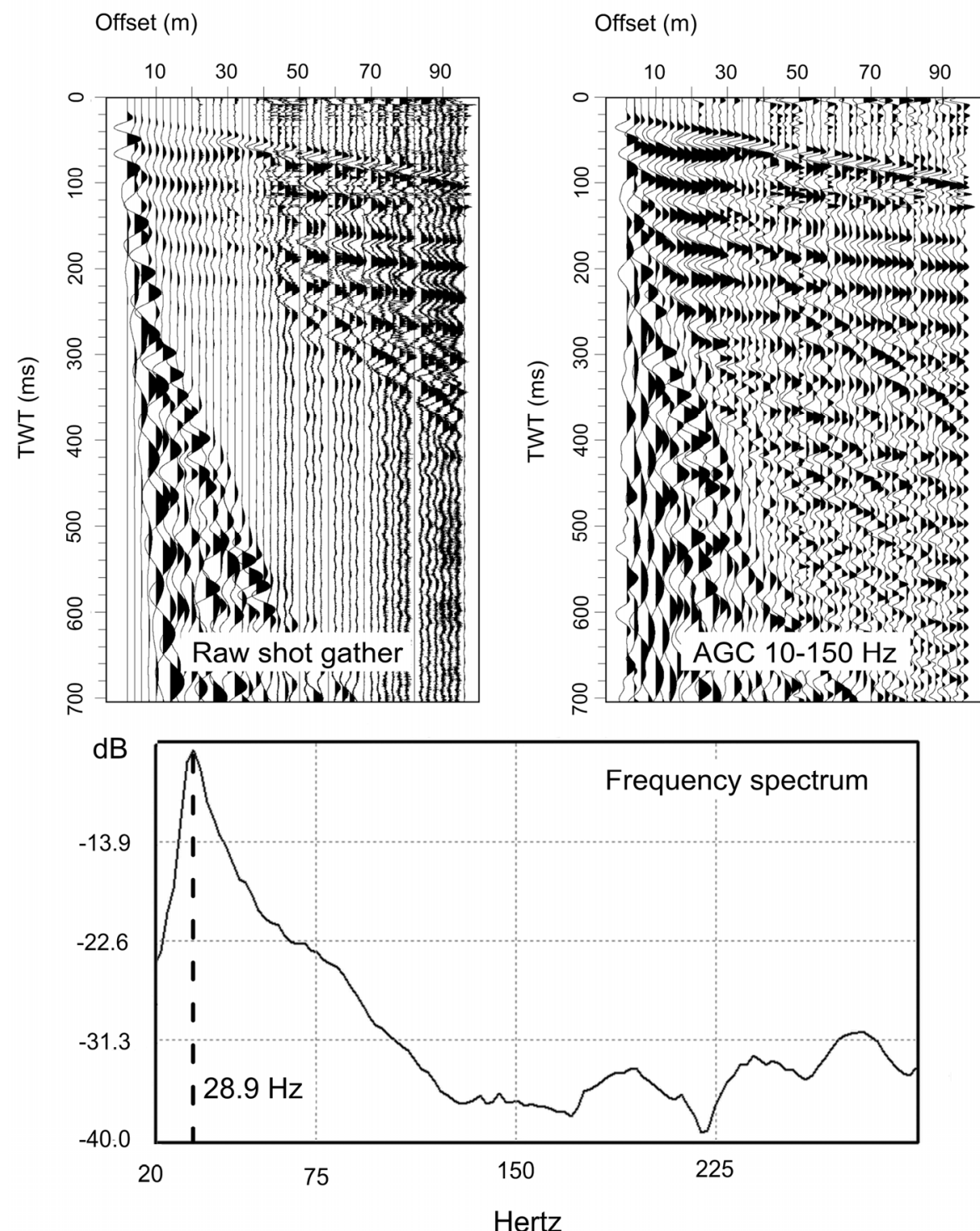

Fig. 9 Example shot gather with the ESS100 accelerated weight dropper with the 4 $\mathrm{kN} / \mathrm{m}$ rubber band and iron plate obtained on very soft and porous ploughed field surface on Barje 2 profile. Note the low frequency of reflections and near-absence of high frequency energy content in the frequency spectrum.

sediments. Pre-Quaternary basement is very good mapped as a dipping seismic reflector at $155 \mathrm{~ms}$ TWT at the eastern end of the profile, rising to $140 \mathrm{~ms}$ TWT at the western end of the profile.

No profile sections are shown for shotgun seismic source in saturated soil and for ESS100 accelerated weight dropper on paved road since the sections obtained with these source - surface combinations are too short.

\section{DISCUSSION OF RESULTS}

\section{Seismic shotgun fired in water-saturated vs.} unsaturated soil

The seismic shotgun produces significantly less coherent noise when the shot is located in water- saturated soil. Reduction in noise includes a significant reduction of air-coupled wave and a nearcomplete absence of ground roll. This is important, as ground roll represents the most important noise component in seismic reflection data. Also, the $12 \%$ observed increase in peak frequency is favourable for better resolution (Table 4). A significant (42\%) increase in $\mathrm{S} / \mathrm{N}$ ratio is observed in shots into saturated soil compared to shots into unsaturated soil with $\mathrm{S} / \mathrm{N}$ ratio $5.8 \pm 2.0$ for shots into saturated soil and $4.1 \pm 2.3$ for shots into unsaturated soil (Table 3 ).

Pullan and Hunter (1987) obtained similar results in testing the 12-gauge "Buffalo gun", a similar source to the seismic shotgun we used. Shots made with the "Buffalo gun" in damp or water-saturated sediments 
ESS100 $+4 \mathrm{kN} / \mathrm{m}$ rubber band + iron plate on grassland surface

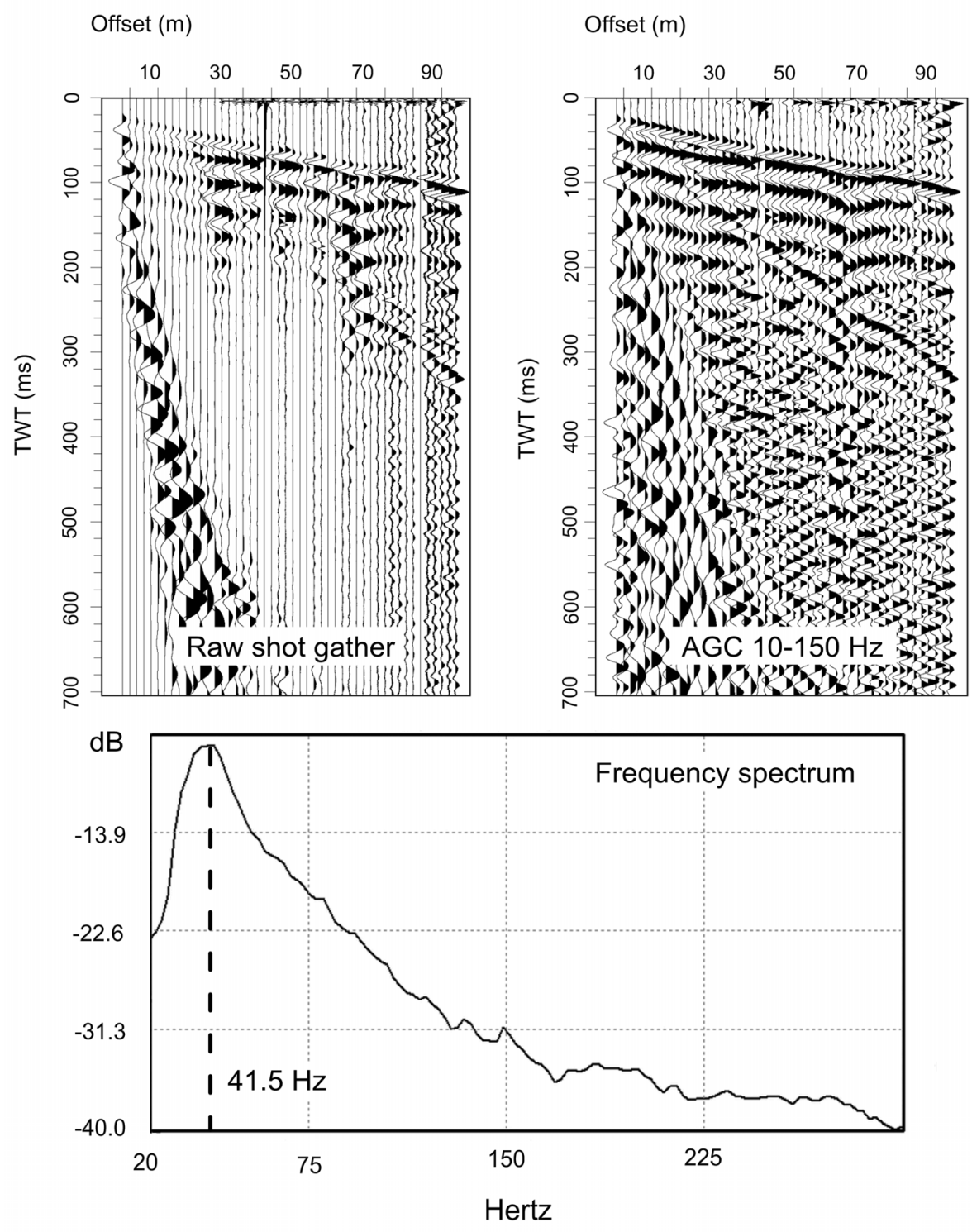

Fig. 10 Example shot gather and frequency spectrum with the ESS100 accelerated weight dropper with the $4 \mathrm{kN} / \mathrm{m}$ rubber band and iron plate on grassland surface on Barje 3 profile. Note the comparatively low frequency of reflections.

produced significantly better results, especially in the high frequency range and reduced air-coupled wave compared to shots made into dry sediments.

\section{Seismic shotgun vs. ESS100 accelerated weight dropper on soft grassland surface}

The side-by-side comparison of the ESS100 system and shotgun on a particularly soft grassland surfaře (logistically suitable for both seismic sources) showed that seismic shotgun produces a significantly better $\mathrm{S} / \mathrm{N}$ ratio and improved appearance of seismic horizons. The ESS100 suffered from strong air-coupled wave and lower $\mathrm{S} / \mathrm{N}$ ratio. A similar result was obtained by Miller et al. (1994). The data obtained with the seismic shotgun produced a significantly improved $\mathrm{S} / \mathrm{N}$ ratio
$(14.1 \pm 5.1)$ compared to the accelerated weight dropper $(4.3 \pm 1.1)$, a ratio of $3.3 x$. Therefore on Barje 1 profile the shotgun was selected as the seismic source. Both $\mathrm{S} / \mathrm{N}$ ratios are high, which is attributed to strong seismic reflectors at this location. Note that neither value is in Table 3 due to the small data sample. The overall $\mathrm{S} / \mathrm{N}$ ratio of shot gathers obtained on Barje 1 profile with the seismic shotgun is lower (Table 3). No statistical analysis of dominant frequencies of significant signals was made due to the small data set.

\section{ESS100 accelerated weight dropper with $4 \mathrm{kN} / \mathrm{m}$ band on different surfaces}

Highly significant differences were observed in ESS100 data quality on different surface types, 
ESS100 $+4 \mathrm{kN} / \mathrm{m}$ rubber band + iron plate on grassland (profile Barje 3, CMP 999)

Offset (m)

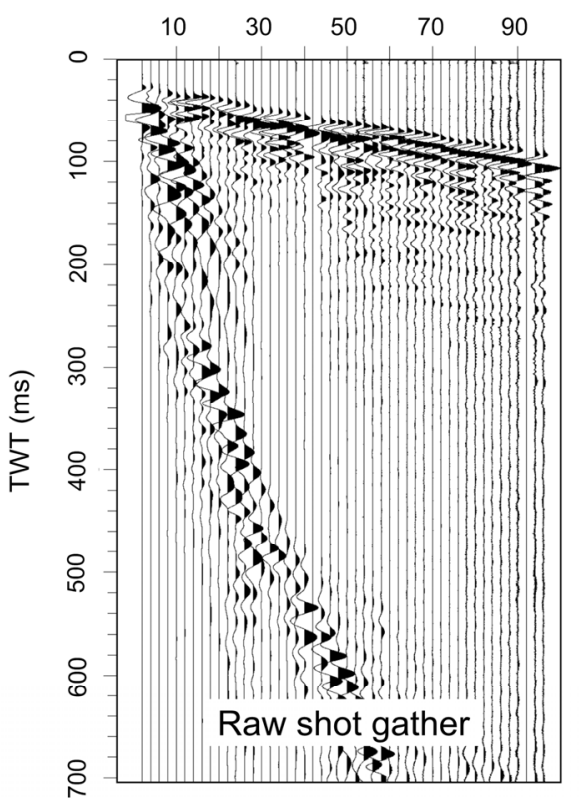

Offset (m)

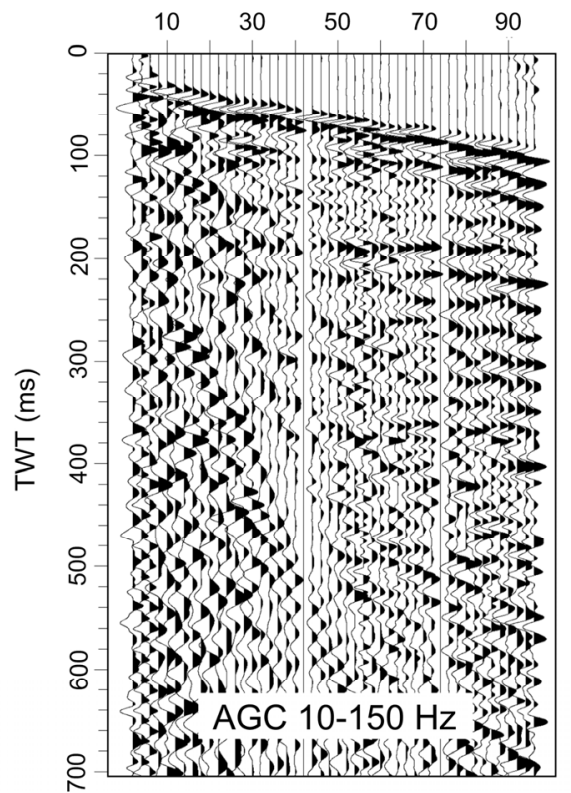

Fig. 11a Example shot gather and frequency spectrum with the ESS100 accelerated weight dropper with the $4 \mathrm{kN} / \mathrm{m}$ rubber band and iron plate on grassland surface on Barje 3 profile.

\section{ESS100 + $4 \mathrm{kN} / \mathrm{m}$ rubber band + iron plate on grassland (profile Barje 3, CMP 1100)}

Offset $(m)$

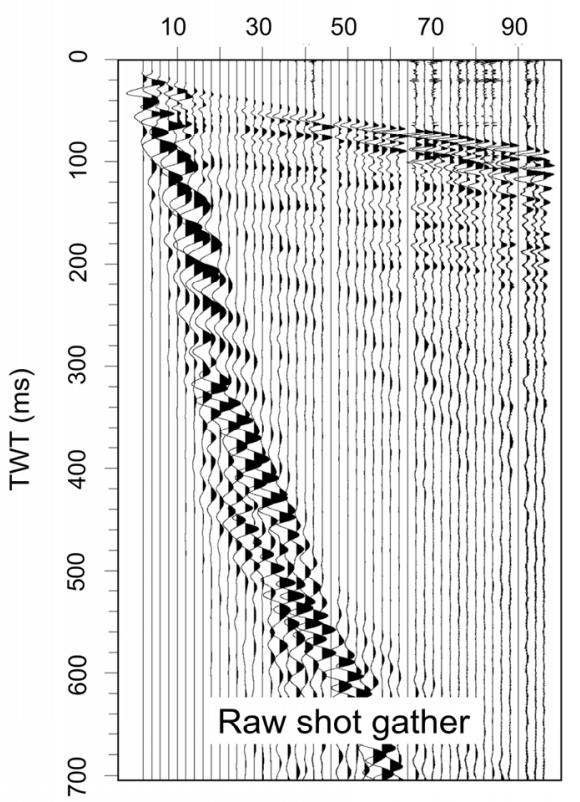

Offset (m)

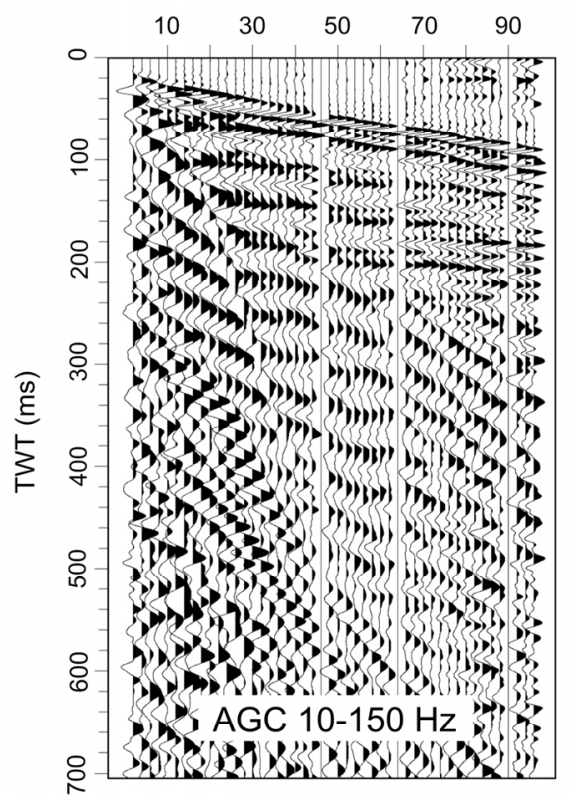

Fig. 11b Another example shot gather and frequency spectrum with the ESS100 accelerated weight dropper with the $4 \mathrm{kN} / \mathrm{m}$ rubber band and iron plate on grassland surface on Barje 3 profile, $51 \mathrm{~m}$ west of shot gather in Figure 11a. Note the improved visibility of reflections and resolution compared to Figures 10 and $11 \mathrm{a}$. 


\section{ESS100 + $4 \mathrm{kN} / \mathrm{m}$ rubber band + iron plate on paved road surface}

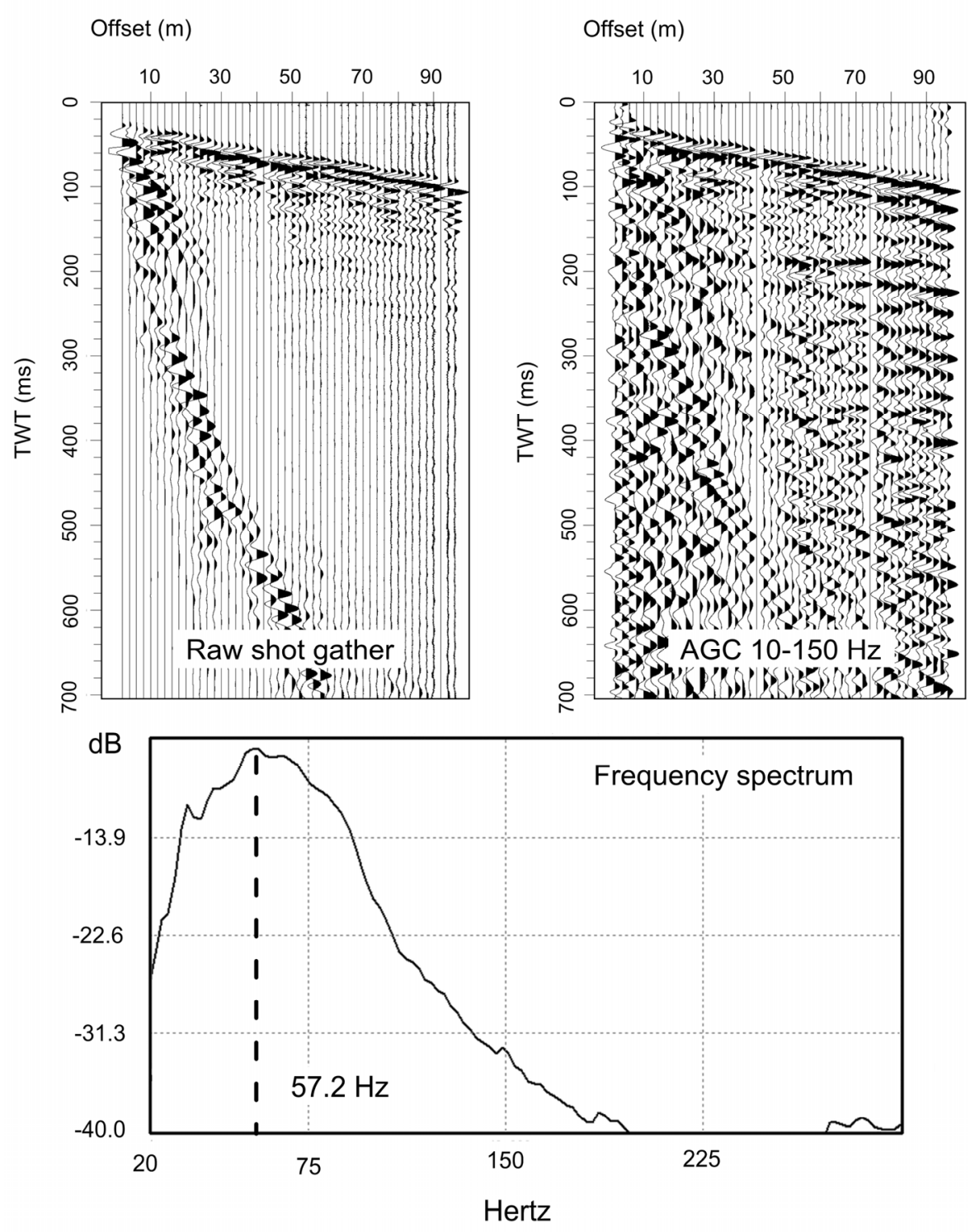

Fig. 12 Example shot gather and frequency spectrum with the ESS100 accelerated weight dropper with the $4 \mathrm{kN} / \mathrm{m}$ rubber band and iron plate on paved road surface on Barje 4 profile.

permitting their characterization. The $\mathrm{S} / \mathrm{N}$ ratio analysis showed a systematic decrease in $\mathrm{S} / \mathrm{N}$ ratio from solid asphalt surface to gravel road surface and grassland surface (Table 3 ). This is not unexpected as the asphalt surface is the hardest and dampens the source impact very little, however, it is somewhat surprising that the $\mathrm{S} / \mathrm{N}$ ratio is over $3 \mathrm{x}$ higher than on gravel roads. This effect is attributed solely to the surface at the source location, as the surfaces into which the geophones were planted were identical.

Data obtained with the accelerated weight dropper on asphalt also shows a large standard deviation, which reflects operational difficulties of using a (spring-loaded) weight dropper system on a very hard asphalt surface. Weight impact at a right angle produced rebound of variable size. This reduced the $\mathrm{S} / \mathrm{N}$ ratio in the data. Rebound was nearly or completely absint when the impact occurred at a slight angle $\left(2-4^{\circ}\right.$ from vertical).

The $\mathrm{S} / \mathrm{N}$ ratio in data obtained on gravel roads $(3.7 \pm 1.3)$ and ploughed field $(2.8 \pm 1.5)$ is similar, although (as expected) it is higher on gravel roads. This surface produces some impact dampening as evidenced by $3-8 \mathrm{~cm}$ deep depressions formed by four consecutive impacts on the iron plate. The fairly small standard deviation in $\mathrm{S} / \mathrm{N}$ ratio is also reflected in high uniformity of data. This is highly desirable, as constant processing can be applied over large segments of seismic profiles. Data obtained on the ploughed field suffers from strong high-frequency 


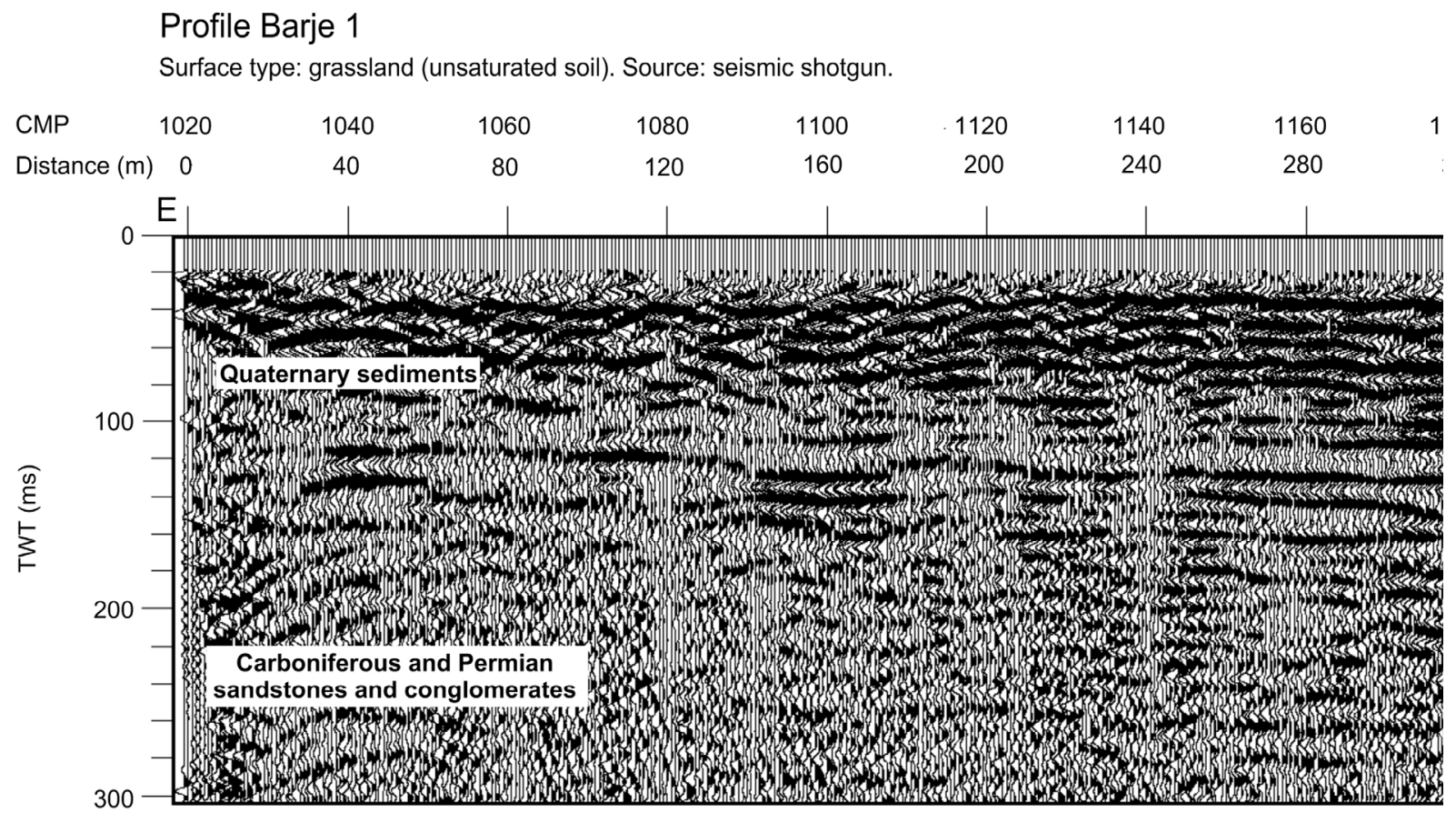

Fig. 13 Seismic profile Barje 1 obtained with the seismic shotgun and shots into unsaturated soil. Discontinuous seismic horizons are visible in Quaternary sediments. The pre-Quaternary basement is shown by the slightly dipping seismic horizon running from $120 \mathrm{~ms}$ TWT on the left (east, CDP 1020) end of the profile to $130 \mathrm{~ms}$ TWT on the right end of the profile (west, CDP 1200).

\section{Profile Barje 2}

Surface type: ploughed field. Source: ESS100 + $4 \mathrm{kN} / \mathrm{m}$ rubber band + iron plate.

$\begin{array}{lccccccc}\text { CMP } & 1000 & 1020 & 1040 & 1060 & 1080 & 1100 & 1120 \\ \text { Distance }(\mathrm{m}) & 0 & 40 & 80 & 120 & 160 & 200 & 240\end{array}$

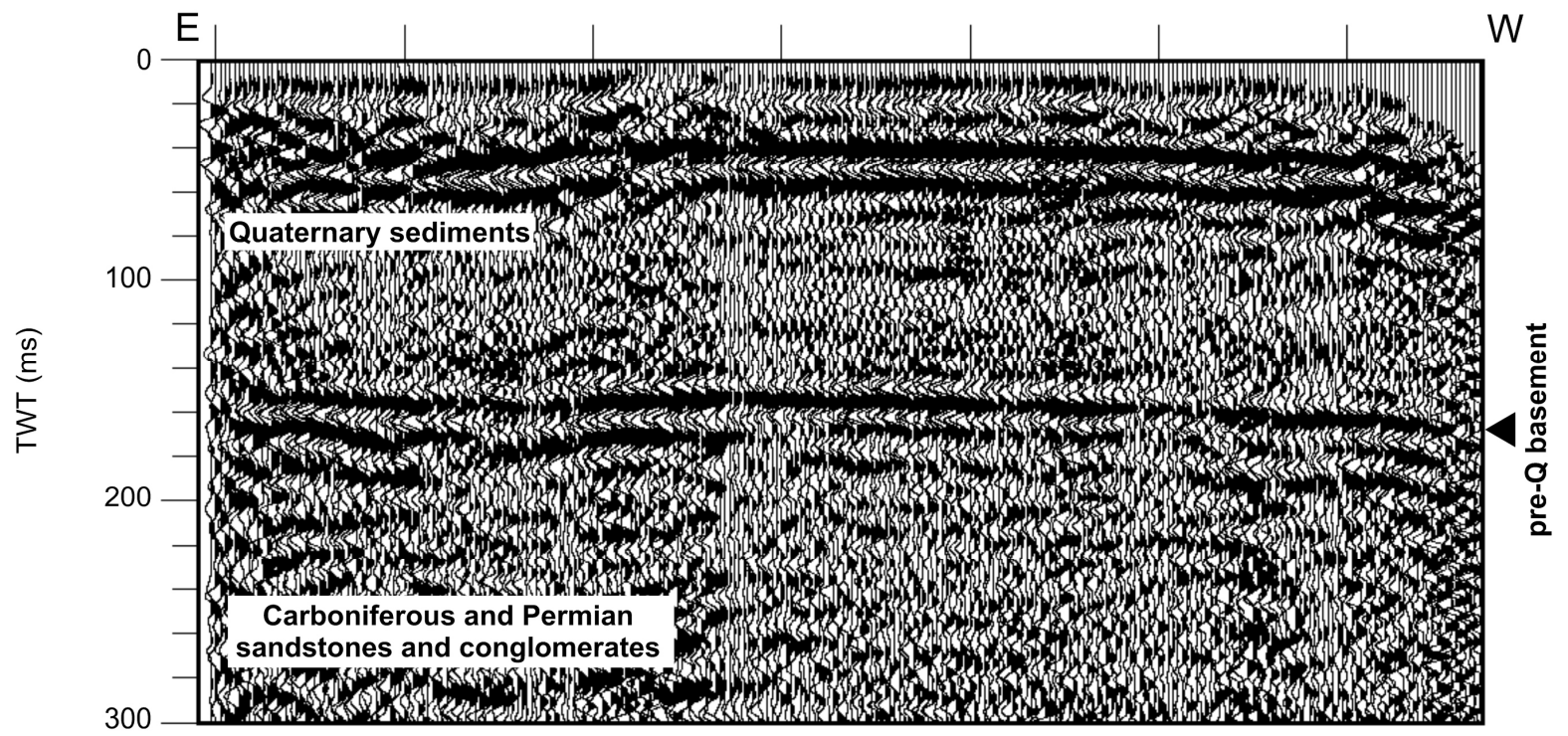

Fig. 14 Seismic profile Barje 2 obtained using the ESS100 and 4 kN/m rubber band on ploughed field surface. The pre-Quaternary basement is shown by the near-horizontal, very slightly dipping seismic horizon between $155 \mathrm{~ms}$ TWT on the left (east, CDP 1000) and $165 \mathrm{~ms}$ TWT on the right end of the profile (west, CDP 1120). 


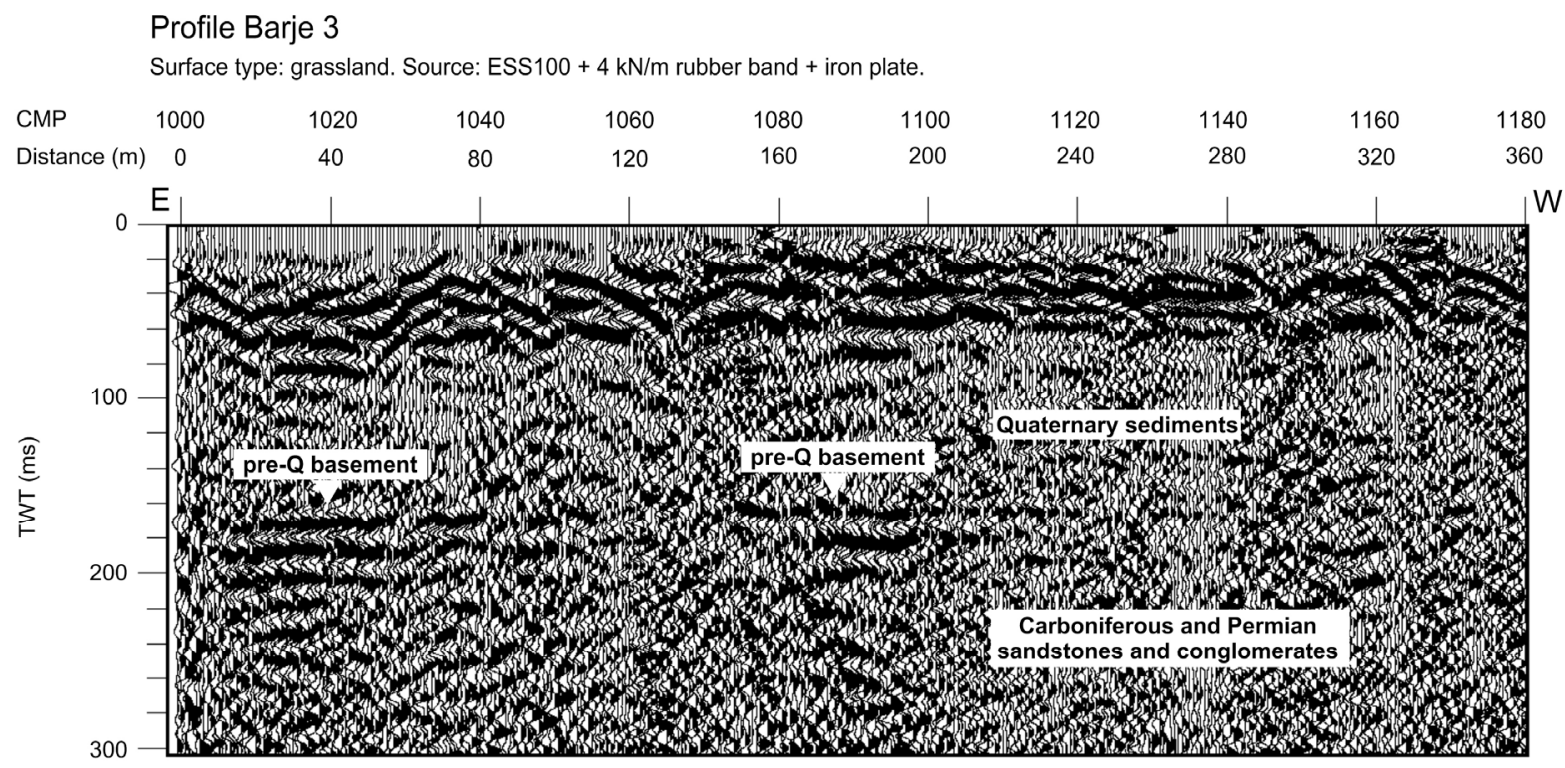

Fig. 15 Seismic profile Barje 3 obtained using the ES100 and 4 kN/m rubber band on grassland surface. The preQuaternary basement is shown by the horizontal discontinuous seismic horizon at $165 \mathrm{~ms}$ TWT.

Profile Barje 4

Surface type: gravel road. Source: ESS100 + $4 \mathrm{kN} / \mathrm{m}$ rubber band + iron plate.

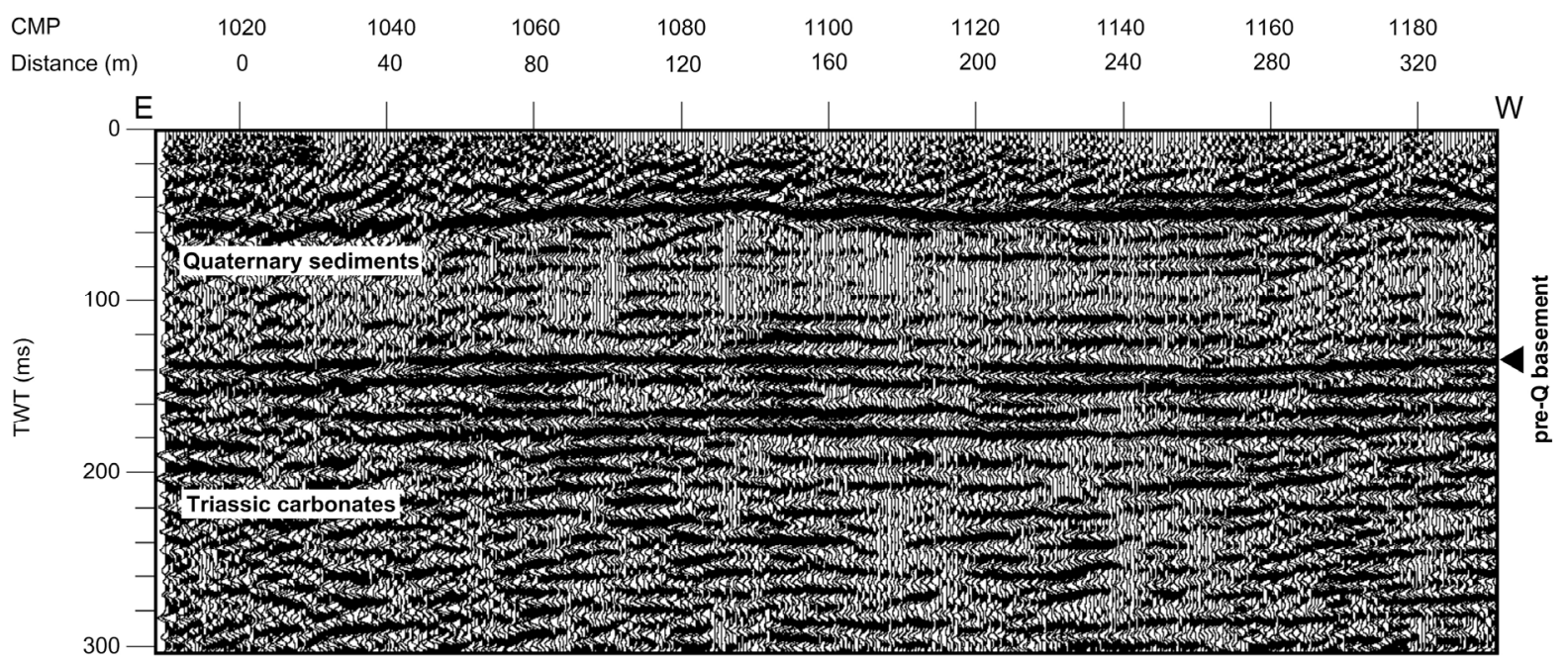

Fig. 16 Seismic profile Barje 4 obtained using the ES100 and 4 kN/m rubber band on hard gravel road surface. The pre-Quaternary basement is shown by the horizontal continuous seismic horizon at $140 \mathrm{~ms}$ TWT.

attenuation. This effect is obvious both in peak frequency of seismic reflections and in $\mathrm{S} / \mathrm{N}$ ratio on far-offset traces. Both the peak frequency and the $\mathrm{S} / \mathrm{N}$ ratio are the lowest of all surface types. High attenuation is also shown by the lowest peak frequencies for coherent noise of all surface types. This is not surprising as the surface is soft and highly compressible. Four consecutive impacts generated pits about $20-25 \mathrm{~cm}$ deep, in some places as much as $40-50 \mathrm{~cm}$ (these locations were considered unsuitable for data acquisition).
Data obtained on grassland shows much less uniformity, both in peak frequencies of seismic reflections and in $\mathrm{S} / \mathrm{N}$ ratio. This is due to the heterogeneity of grassland surfaces and also probable near-subsurface heterogeneity. The $\mathrm{S} / \mathrm{N}$ ratio of $6.1 \pm$ 3.0 is higher than for gravel road and ploughed field surfaces, however, the large standard deviation is indicative of high variations in shot gather quality. Indeed, grassland surfaces show high variations in stiffness and water saturation - in transient areas between cultivated grass fields and marshland the 


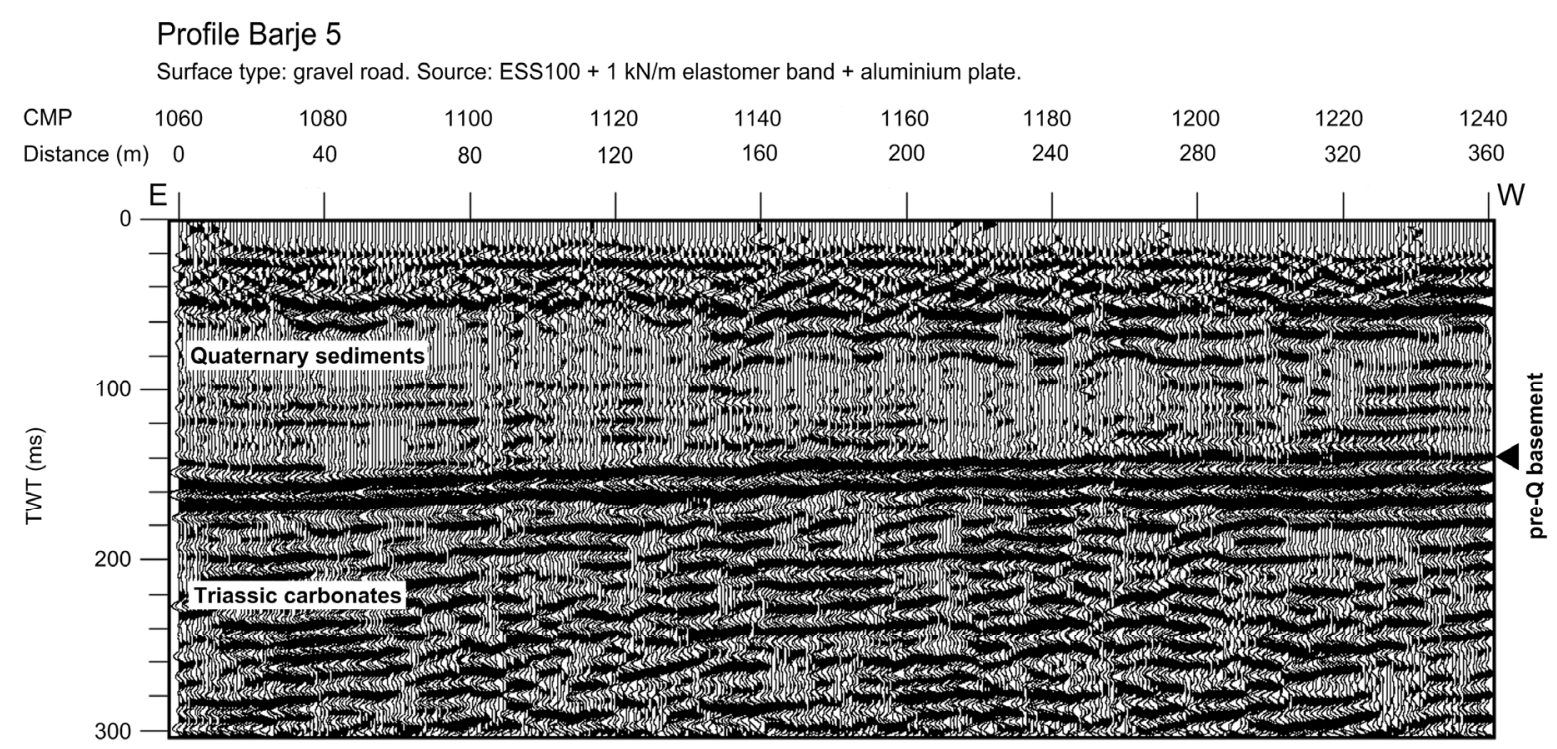

Fig. 17 Profile Barje 5 obtained using the ES100 accelerated weight dropper and $1 \mathrm{kN} / \mathrm{m}$ elastomer band on hard gravel road surface. The pre-Quaternary basement is shown by the dipping seismic horizon at $155 \mathrm{~ms}$ TWT on the left (east, CDP 1060) and $140 \mathrm{~ms}$ TWT on the right (west, CDP 1240) end of the seismic profile.

surface is highly elastic and soft. The seismic source produces significant rebound as well as $5-15 \mathrm{~cm}$ deep pits after four consecutive impacts.

The dominant frequency of seismic reflections (Table 6) was the highest on paved road $(60.0 \mathrm{~Hz})$, followed by the grassland $(32.2 \mathrm{~Hz})$, gravel road $(29.6 \mathrm{~Hz}$, with secondary peak at $80.2 \mathrm{~Hz}$ ) and ploughed field $(28.9 \mathrm{~Hz})$. The high dominant frequency in paved road shot gathers is expected due to low attenuation of signal. Dominant frequencies on gravel road, grassland and ploughed field surfaces are very similar, all close to $30 \mathrm{~Hz}$. Due to the large data variability on paved road surface and otherwise very similar dominant frequencies on other surfaces, the $\mathrm{S} / \mathrm{N}$ ratio is the deciding factor in surface type selection with this seismic source.

\section{ESS100 accelerated weight dropper with $1 \mathrm{kN} / \mathrm{m} \mathrm{vs}$. $4 \mathrm{kN} / \mathrm{m}$ band}

The $1 \mathrm{kN} / \mathrm{m}$ elastomer band and aluminium plate combination yields a higher $\mathrm{S} / \mathrm{N}$ ratio $(9.4 \pm 4.4)$ than the $4 \mathrm{kN} / \mathrm{m}$ rubber band and iron plate $(3.7 \pm 1.3)$. The significance of this high difference is, however, questionable since the profile section on which the first combination was used is $1 \mathrm{~km}$ distant from the location where the second combination was used. The first location is characterized by significantly lower ambient noise (less vegetation) and appears to have a slightly higher impedance contrast at seismic horizons. For the target depth range of $200-300 \mathrm{~m}$, both combinations produce sufficient $\mathrm{S} / \mathrm{N}$ ratio for high data quality (Figures 16 and 17).

\section{Influence of changing geological conditions}

Some variability in seismic horizon clarity can be a result of changing geological structure and impedance contrast. This may be seen in profiles Barje 4 and Barje 5, both acquired using the accelerated weight dropper on gravel roads, but with different elastic bands. The pre-Quaternary basement boundary is well visible on both profiles, however, seismic reflectors in Quaternary sediments are slightly more apparent in Barje 4 than in Barje 5 (the same processing workflow was applied for both profiles). However, as the Quaternary sediments of the entire investigated area are the result of rather uniform sedimentation (lacustrine sedimentation over a large area in the upper part and distal large alluvial fan deposition in the lower area), large differences in reflectivity are not expected. Thus we attribute most of the data variability to the surface type and seismic source selection.

\section{Improving resolution and $\mathrm{S} / \mathrm{N}$ ratio}

In some cases, due to logistical considerations, source availability or other factors, less than optimal source-surface combination choices must be made. Data quality can be improved during data acquisition by multiple shot stacking (for ESS100) and use of analog filters. Further improvement to resolution and $\mathrm{S} / \mathrm{N}$ ratio can be made by removing random noise with frequency filtering and source-generated coherent noise by $\mathrm{f}-\mathrm{k}$ filtering. Additional resolution improvement can be made with the use of deconvolution algorithms. With careful acquisition planning and consideration of source and surface specifics, useful data can be obtained on the majority of possible source-surface combinations. 


\section{CONCLUSIONS}

Two different seismic sources were used on the Ljubljana Moor in the course of acquisition of a $5.5 \mathrm{~km}$ long HRS profile. The sources were evaluated for suitability on different surface types encountered on the Moor. Eight different sourcesurface condition combinations were tested. The two sources were directly compared only on (soft) grassland, but this is the only surface type on which both sources could likely be used.

Both sources were found suitable for highresolution shallow seismic reflection profiling in given environment (Figures $13-17$ ). Field comparison showed that careful selection of the seismic source is advisable, depending on the ground surface conditions. However, other considerations also play a role, such as land use permits and cost considerations. The seismic shotgun requires comparatively expensive shells and an operator with gun permit. Final shotgun operational cost per shot is about $5 \mathrm{x}$ higher than for the ESS100 accelerated weight dropper.

The seismic shotgun was found to be the most suitable for marshlands due to its simpler logistics, as well as the possibility of placing the shots into watersaturated soil. Thus, the seismic shotgun is the most favourable source for marshlands with shallow underground water table or high water saturation of soil. The near-complete absence of ground roll and significantly reduced air wave, as well as high source energy provide high $\mathrm{S} / \mathrm{N}$ ratio for shots into saturated soil, compared to shots into unsaturated soil.

The accelerated weight dropper system was superior for gravel and paved road surfaces. Grassland results indicate the accelerated weight dropper to be generally superior, however, the seismic shotgun produced better results on particularly soft grassland surface. Thus, when used on this surface type, a careful side-by-side comparison of both sources is advisable.

The accelerated weight dropper system was used with two different bands. It was found to produce higher $\mathrm{S} / \mathrm{N}$ ratio when used with the $1 \mathrm{kN} / \mathrm{m}$ elastomer band and aluminium plate than with the $4 \mathrm{kN} / \mathrm{m}$ rubber band and iron plate. The replacement $4 \mathrm{kN} / \mathrm{m}$ rubber band was used due to better availability after a series of breakages of the original $1 \mathrm{kN} / \mathrm{m}$ elastomer bands. The significance of this result requires further analysis. Both configurations produced good and consistent data.

Responses of four different surface types to the accelerated weight dropper seismic source were analysed. Asphalt surface produced the highest $\mathrm{S} / \mathrm{N}$ ratio of all surfaces as well as a high frequency response. On asphalt, however, rebound problems caused very high variability in shot gather quality, making the data heterogeneous and less favourable for processing. Only in optimal shot conditions, the asphalt surface produces the best seismic data.
The gravel road surface produced high-quality seismic data with the accelerated weight dropper system. The $\mathrm{S} / \mathrm{N}$ ratio is, however, lower than on asphalt surface, but due to consistent results, as shown by the low standard deviation, and high dominant frequency of reflections, this source - surface combination produced the best results.

Ploughed field surface is poorly suited for high resolution seismic reflection due to high absorption and attenuation of signal. Both the seismic shotgun and accelerated weight dropper produced comparatively poor results. Seismic shotgun produced strong air wave due to the explosion blast escaping through the porous ground material. Also ground roll was very strong with this source. The accelerated weight dropper was problematic due to the plate sinking into the ground with each consecutive impact, dampening it and reducing source energy. It is thus highly recommended to avoid such surfaces if possible.

Grasslands proved a similarly unsuitable terrain for both seismic sources. The seismic shotgun was problematic due to strong ground roll and air wave. Data obtained with the ESS100 source showed large variations. The surface shows much local variation in stiffness and attenuation of seismic waves. Generally the best seismic sources were found to be: the accelerated weight dropper (regardless of the elastic band and plate used) on hard gravel road surfaces and the seismic shotgun fired into saturated soil. All provided consistently high-quality data. The accelerated weight dropper has poor performance on softer ploughed fields and grasslands as well as on asphalt surface. The seismic shotgun has less consistent performance when used in unsaturated soil. It is thus concluded that for seismic reflection profiling in the Ljubljana Moor hardened gravel roads and/or marshlands with high water saturation should be chosen.

\section{ACKNOWLEDGEMENTS}

The authors are thankful to Robert Stopar, Ivan Majhen and Sandi Kmetič of Geoinženiring d.o.o. for their extensive field support. Ivan Majhen also developed and manufactured the seismic shotgun. Thanks are also due to Jernej Jež and Blaž Milanič of Geological Survey of Slovenia for their extensive field support. This work was done in the scope of research programme Regional Geology (P1-0011 (C)), project Seismotectonic model of the Ljubljana basin (L1-2383) and $\mathrm{PhD}$ work (Slovenian Research Agency grant No. 1000-07-310075) at the Geological survey of Slovenia.

\section{REFERENCES}

Abbott, R.E. and Louie, J.N.: 2001, Geophysical confirmation of low-angle normal slip on the historically active Dixie Valley fault, Nevada. Journal of Geophysical Research, 106, No. 1, 4169-4181. DOI: 10.1029/2000JB900385 
Bachrach, R. and Nur, A.: 1998, High-resolution shallowseismic experiments in sand, part I: Water Table, fluid flow and saturation. Geophysics, 63, No. 1., 12251233. DOI: $10.1190 / 1.1444423$

Bachrach, R., Dvorkin, J. and Nur, A.: 1998, Highresolution shallow-seismic experiments in sand, part II: Velocities in shallow unconsolidated sand. Geophysics, 63, No. 1, 1234-1240. DOI: $10.1190 / 1.1444424$

Bavec, M., Atanackov, J., Celarc, B., Dozet, S., Demšar, M., Gale, L., Jamšek, P., Jež, J., Milanič, B., Novak, M., Poljak, M., Rajver, D. and Toman, M.: 2009, Geological mapping: annual report for 2009. Ljubljana, Geological survey of Slovenia. 107 pp., (in Slovenia).

Bexfield, C.E., McBride, J.H., Pugin, A.J.M., Ravat, D., Biswas, S., Nelson, W.J., Larson, H., Sargent, S.L., Fillerup, M.A., Tingey, B.E., Wald, L., Northcott, M.L., South, J.V., Okure, M.S. and Chandler, M.R.: 2006, Integration of P- and SH-wave high-resolution seismic reflection and micro-gravity techniques to improve interpretation of shallow subsurface structure: New Madrid seismic zone. Tectonophysics, 420, 5-21. DOI: 10.1016/j.tecto.2006.01.024

Breznik, M.: 1975, Underground water of Iška alluvial fan (Podtalnica Iškega vršaja). Geologija, 18, No. 1, 289309, (in Slovenia).

Bruno, P.P., Improta, L, Castiello, A., Villani, F. and Montone, P.: 2010, The Vallo di Diano Fault System: New evidence for an active range-bounding fault in Southern Italy using shallow, high-resolution seismic profiling. Bulletin of Seismological Society of America, 100, No. 2, 882-890.

DOI: $10.1785 / 0120090210$

Büker, F., Green, A. G. and Horstmeyer, H.: 1998, Shallow seismic reflection study of a glaciated valley. Geophysics, 63, No. 4, 1395-1407.

Campbell, G.: 2009, 2D seismic reflection surveys and structural mapping: faults, dips and domes. In: 11th SAGA Biennial Technical Meeting and Exhibition. Swaziland, 16 - 18 September 2009, 319-324. Retrieved on October 28th 2011, from: http://www.sagaonline.co.za/2009Conference/CD\%20 Handout/SAGA\%2009/PDFs/Abstracts_and_Papers/C AMPBELL_paper1.pdf

Chwatal, W., Decker, K. and Roch, K.-H.: 2005, Mapping of active capable faults by high-resolution geophysical methods: example from the central Vienna basin. Austrian Journal of Earth Sciences, 97, 52-59.

Chow, J., Angelier, J. Hua, J.-J., Lee, J.-C. and Sun, R.: 2001, Paleoseismic event and active faulting: from ground penetrating radar and high-resolution seismic reflection profiles across the Chihshang Fault, eastern Taiwan. Tectonophysics, 333, 241-259. DOI: 10.1016/S0040-1951(00)00277-8

Dusar, M., Rijpens, J., Sintubin, M. and Wouters, L.: 2001, Plio-pleistocene fault patterns of the Feldbiss fault system (southern border of the Roer Valley Graben, Belgium). Netherlands journal of geopyhsics / Geologie en Mijnbouw, 80, No. 1, 79-93.

Feroci, M., Orlando, L., Balia, R., Bosman, C., Cardarelli, E. and Deidda, G.: 2000, Some considerations on shallow seismic reflection surveys. Journal of Applied Geophysics, 45, No. 1, 127-139. DOI: 10.1016/S0926-9851(00)00024-0.

Francese, R.G., Hajnal, Z., Schmitt, D. and Zaja, A.: 2007, High resolution seismic reflection imaging of complex stratigraphic features in shallow aquifers. Memorie Descrittive della Carta Geologica d'Italia, LXXVI, 175-192. Retrieved on October 28th 2011, from: http://www.ualberta.ca/ dschmitt/papers/Francese_eta 1_Memoire_Italy_2007.pdf

Green, A.G., Campbell, F.M., Kaiser, A.E., Dom, C., Carpentier, S., Doetsch, J.A., Horstmeyer, H., Nobles, D., Campbell, J., Finnemore, M., Jongens, R, Ghisetti, F., Gorman, R.M., Langridge, R.M. and McClymont, A.F.: 2010, Seismic reflection images of active faults on New Zealand's South Island. 4th International Conference on Environmental and Engineering Geophysics, Chengdu, China, June 2010. Retrieved on October 28th 2011, from: http://www.terrageologica.com/GreenICEEG_2010.pdf DOI: $10.1016 /$ j.tecto.2010.09.016.

Grmiščar, A. and Ocepek, V.: 1967, Boreholes BV-1 and BV-2 on the Ljubljana Moor. Geologija, 10, No. 1, 279-303, (in Slovenia).

Improta, L.F., De, M.I., Piscitelli, S, Bruno, P.P., Burrato, P., Civico, R., Giocoli, A., Iorio, M., Addezio, G.D. and Maschio, L.: 2010, Detecting young, slowslipping active faults by geologic and multidisciplinary high-resolution geophysical investigations: A case study from the Apenine seismic belt, Italy. Journal of Geophysical Research, No. 115, B11307. DOI:10.1029/2010JB000871

Kato, N., Echigo, T., Sato, H., Tateshi, M., Ogino, S., Sakai, S., Toda, S., Koshiya, S., Ito, T., Toyoshima, T., Imaizumi, T., Kato, H. and Abe, S.: 2005, Geologic fault model based on the high-resolution seismic reflection profile and aftershock distribution with the 2004 MidNiigata Prefecture earthquake (M6.8), central Japan. Earth Planets Space, No. 57, 447-452.

Knapp, R.W. and Steeples, D.W.: 1986, High-resolution common-depth-point reflection profiling: Field acquisition parameter design. Geophysics, 51, No. 2, 283-294. DOI: 10.1190/1.1442088.

Mencej, Z.: 1989, The gravel fill beneath the lacustrine sediments of the Ljubljansko barje. Geologija, 31/32, No. 1, 517-553, (in Slovenia).

Miller, R.D., Pullan, S.E., Waldner, J.S. and Haeni, F.P.: 1986, Field comparison of shallow seismic sources. Geophysics, 51, No. 11, 2067-2092. DOI: $10.1190 / 1.1442061$

Miller, R.D and Steeples, D.W.: 1991, Detecting voids in a $0.6 \mathrm{~m}$ coal seam, $7 \mathrm{~m}$ deep, using seismic reflection. Geoexploration, 28, No. 1, 109-119. DOI: 10.1016/0016-7142(91)90043-C

Miller, R.D., Pullan, S.E., Steeples, D.W. and Hunter, J.A.: 1992, Field comparison of shallow seismic sources near Chino, California. Geopysics, 57, No. 5, 693-709. DOI: 10.1190/1.1443283

Miller, R.D., Pullan, S.E., Steeples, D.W. and Hunter, J.A.: 1994, Field comparison of shallow P-wave seismic sources near Houston, Texas. Geophysics, 59, No. 11, 1712-1728. DOI: 10.1190/1.1443558

Premru, U.: 1983, Basic geological map 1 : 100 000, explanatory booklet for sheet Ljubljana (Osnovna geološka karta 1:100 000, Tolmač za list Ljubljana). Zvezni geološki zavod, Beograd, 72 pp., (in Slovenia)

Pullan, S.E. and MacAulay, H.A.: 1987, An in-hole shotgun source for engineering seismic surveys. Geopyhsics, 52, No. 7, 985-996. DOI: 10.1190/1.1442367

Pullan, S.E. and Hunter, J.A.: 1990, Delineation of buried bedrock valleys using the optimum offset shallow seismic reflection technique. In: S. H. Ward (ed): 
Geotechnical and Environmental Geophysics, vol. 3, Geotechnical, Invest. Geophys., 5, 75-88.

Steeples, D.W. and Miller, R. D.: 1990, Seismic reflection methods applied to engineering, environmental, and groundwater problems. In: S. H. Ward (ed): Geotechnical and Environmental Geophysics, 3, Geotechnical Invest. Geophys., 5, 1-30.

Steeples, D.W. and Miller, R.D.: 1998, Avoiding pitfalls in shallow seismic reflection surveys. Geophysics, 63, No. 4, 1213-1224. DOI: 10.1190/1.1444422

Steeples, D.W.: 2000, A review of shallow seismic methods. Annali di geofisica, 43, No. 6, 1021-1044.

Šercelj, A.: 1965, Paleobotanic research and the history of Ljubljana Moor. Geologija, 8, No. 1, 5-27, (in Slovenia).

Sugiyama, Y., Mizuno, K., Nanayama, F., Sugai, T., Yokota, H., Hosoya, T., Muira, K., Takemura, K. and Kitada, N.: 2003, Study of blind thrust faults underlying Tokyo and Osaka urban areas using a combination of high-resolution seismic reflection profiling and continuous coring. Annals of Geophysics, 5, No. 5, 1071-1085.

Wang, C.-L., Chiu, J.-D. and Lin, L.-A.: 2001, The detection of three active faults in the Taoyuan terrace, northwestern Taiwan using ' 1 sec' shallow reflection seismic. Geophysical research letters, 32, No. 1, 8313-8317.

Wyatt, D.E., Wadell, M.G. and Boyd Sexton, G.: 1996, Geophysics in shallow faults in unconsolidated sediments. Ground Water, 34, No. 2, 326-334.

DOI: 10.1111/j.1745-6584.1996.tb01892.x 